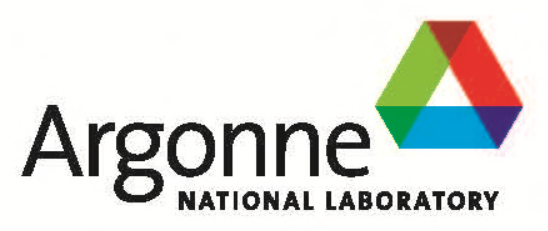

Gas Generation during Waste Treatment of Acidic Solutions from the Dissolution of Irradiated LEU Targets for ${ }^{99}$ Mo Production

Nuclear Engineering Division 


\section{About Argonne National Laboratory}

Argonne is a U.S. Department of Energy laboratory managed by UChicago Argonne, LLC

under contract DE-AC02-06 CH11357. The Laboratory's main facility is outside Chicago, at 9700 South Cass Avenue, Argonne, Illinois 60439. For information about Argonne

and its pioneering science and technology programs, see www.anl.gov.

\section{DOCUMENT AVAILABILITY}

Online Access: U.S. Department of Energy (DOE) reports produced after 1991 and a growing number of pre-1991 documents are available free via DOE's SciTech Connect (http://WwW.osti.gov/scitech/)

Reports not in digital format may be purchased by the public from the National Technical Information Service (NTS):

U.S. Department of Commerce

National Technical Information Service

5301 Shawnee Rd

Alexandria, VA 22312

unw.ntis.gov

Phone: (800) 553-NTIS (6847) or (703)

605-6000 Fax: (703) 605-6900

Email: orders@ntis.gov

Reports not in digital format are available to DOE and DOE contractors from the Office of Scientific and Technical Information (OST):

U.S. Department of Energy

Office of Scientific and Technical Information

P.O. Box 62

Oak Ridge, TN 37831-0062

unw.osti.gov

Phone: (865) 576-8401

Fax: (865) 576-5728

Email: reports@osti.gov

\section{Disclaimer}

This report was prepared as an account of work sponsored by an agency of the United States Government. Neither the United States Government nor any agency thereof, nor UChicago Argonne, LLC, nor any of their employees or officers, makes any warranty, express or implied, or assumes any legal liability or responsibility for the accuracy, completeness, or usefulness of any information, apparatus, product, or process disclosed, or represents that its use would not infringe privately owned rights. Reference herein to any specific commercial product, process, or service by trade name, trademark, manufacturer, or otherwise, does not necessarily constitute or imply its endorsement, recommendation, or favoring by the United States Government or any agency thereof. The views and opinions of document authors expressed herein do not necessarily state or reflect those of the United States Government or any agency thereof, Argonne National Laboratory, or UChicago Argonne, LLC. 


\section{Gas Generation during Waste Treatment of Acidic Solutions from the Dissolution of Irradiated LEU Targets for ${ }^{99}$ Mo Production}

by

Allen J. Bakel, Cliff Conner, Kevin Quigley, and George F. Vandegrift

Nuclear Engineering Division, Argonne National Laboratory

Completed: September 2002

Published: January 2017 



\section{CONTENTS}

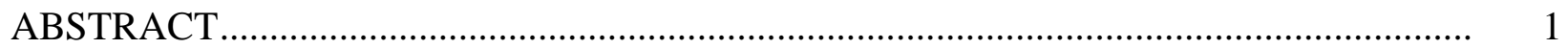

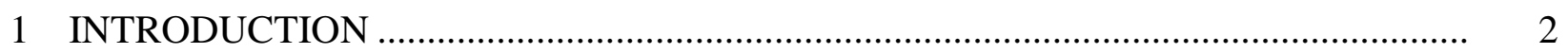

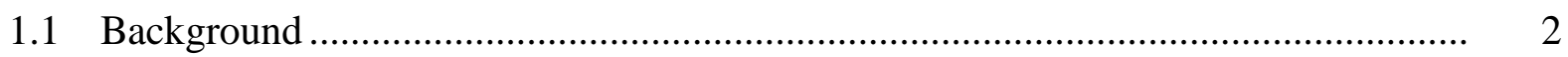

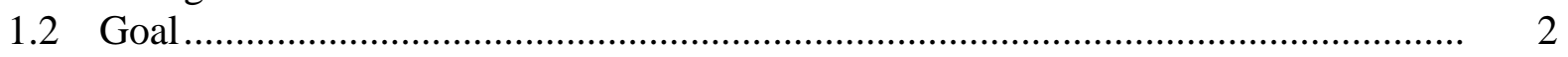

2 EXPERIMENTAL _....................................................................................................

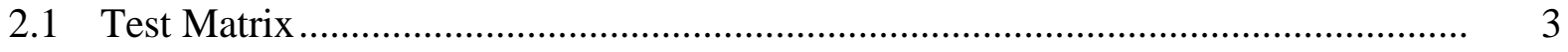

2.2 Glass Evaporator/Precipitator ………………………………………………...... 4

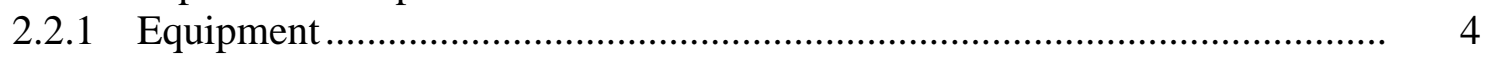

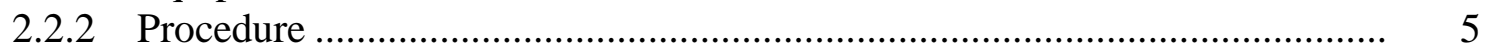

2.3 Steel Calciner …………………………………............................................... 5

2.3.1 Equipment ................................................................................ 5

2.3.2 Procedure ....................................................................................... 7

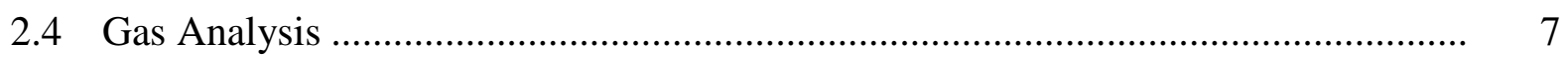

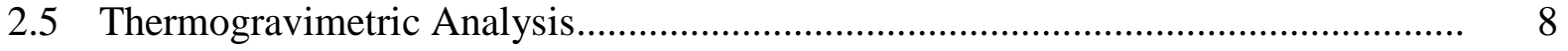

3 RESULTS AND DISCUSSION …………….....................................................

3.1 Direct Calcination Process ............................................................................................ 9

3.1.1 Evaporation/Precipitation .................................................................... 9

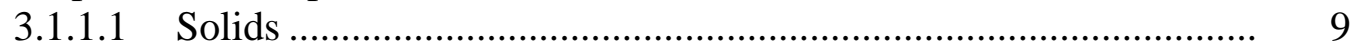

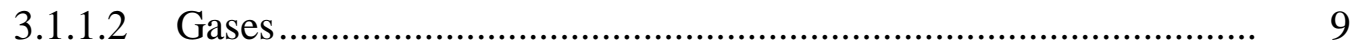

3.1.1.3 Reactions........................................................................ 12

3.1.2 Calcinations of UNH.................................................................... 12

3.1.2.1 Solids ……................................................................... 12

3.1.2.2 Gases .................................................................... 16

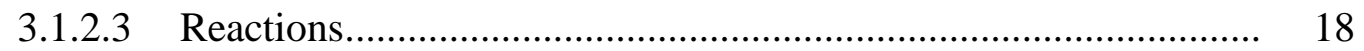

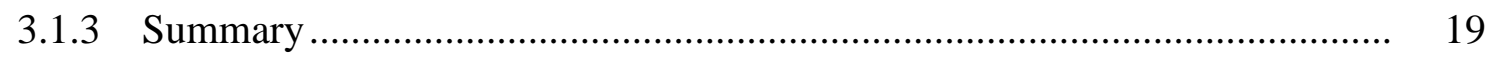

3.2 Uranyl Oxalate Precipitation Process ……………………………………….......... 19

3.2.1 Evaporation ............................................................................. 20

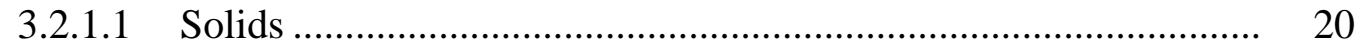

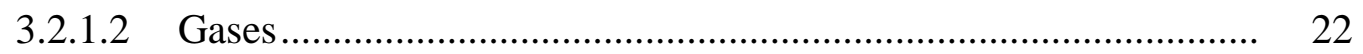

3.2.1.3 Reactions................................................................................ 22

3.2.2 Calcinations............................................................................... 23

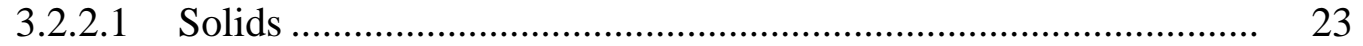

3.2.2.2 Gases ........................................................................ 29

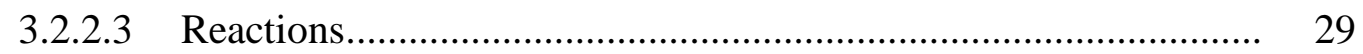

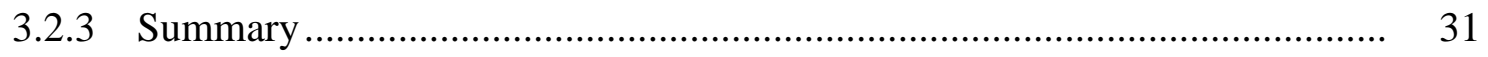

3.3 Comparison of the Two Processes ........................................................................ 32 


\section{CONTENTS (Cont.)}

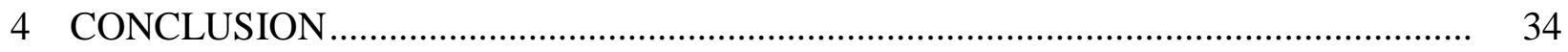

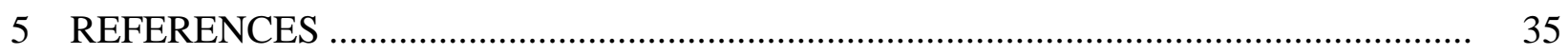

\section{FIGURES}

1 Schematic of all-glass calciner apparatus built in our laboratory to study reactions in direct calcination and oxalate processes .................................................................. 4

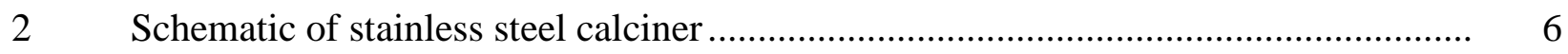

$3 \quad$ Schematic of stainless steel container in stainless steel calciner .................................... 6

$4 \quad$ Schematic of calciner head for stainless steel calciner ……………………................... 7

$5 \quad \mathrm{XRD}$ pattern for solids formed by evaporation of $\mathrm{UNH} / \mathrm{HNO}_{3}$ solution with air sparge gas .................................................................................................... 10

$6 \quad \mathrm{XRD}$ pattern for solids formed by evaporation of $\mathrm{UNH} / \mathrm{HNO}_{3}$ solution with $\mathrm{He}$ sparge gas ........................................................................................................ 10

$7 \quad \mathrm{XRD}$ pattern for solids formed by evaporation of $\mathrm{UNH} / \mathrm{HNO}_{3}$ solution with $4 \%$ $\mathrm{H}_{2} / 96 \% \mathrm{He}$ sparge gas ................................................................................... 11

8 Photograph of material calcined in air at $400^{\circ} \mathrm{C}$ and $600^{\circ} \mathrm{C}$ from $\mathrm{UNH}$

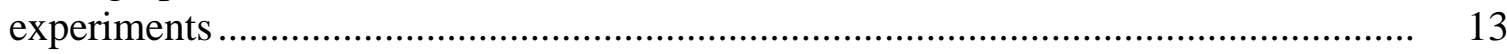

$9 \quad \mathrm{XRD}$ pattern for solids formed by calcinations at $400^{\circ} \mathrm{C}$ of UNH in air sparge gas .... 14

10 XRD pattern for solids formed by calcinations at $600^{\circ} \mathrm{C}$ of UNH in air sparge gas .... 14

11 Photograph of material calcined in $4 \% \mathrm{H}_{2} / 96 \% \mathrm{He}$ at $400^{\circ} \mathrm{C}$ and $600^{\circ} \mathrm{C}$ from UNH experiments ........................................................................................... 15

12 XRD pattern for solids formed by calcinations at $400^{\circ} \mathrm{C}$ of UNH in $4 \% \mathrm{H}_{2} / 96 \%$ He sparge gas .............................................................................................. 15

$13 \mathrm{XRD}$ pattern for solids formed by calcinations at $600^{\circ} \mathrm{C}$ of $\mathrm{UNH}$ in $4 \% \mathrm{H}_{2} / 96 \%$ He sparge gas ............................................................................................... 16

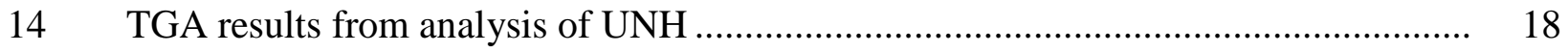




\section{FIGURES (Cont.)}

15 XRD pattern for solids formed by precipitation of uranyl oxalate and evaporation of $\mathrm{HNO}_{3}$ and water with air sparge gas

16 XRD pattern for solids formed by precipitation of uranyl oxalate and evaporation of $\mathrm{HNO}_{3}$ and water with $\mathrm{He}$ sparge gas

17 XRD pattern for solids formed by precipitation of uranyl oxalate and evaporation of $\mathrm{HNO}_{3}$ and water with $4 \% \mathrm{H}_{2} / 96 \% \mathrm{He}$ sparge gas ......

18 Photograph of material calcined in air at $400^{\circ} \mathrm{C}$ and $600^{\circ} \mathrm{C}$ from uranyl oxalate ........

19 XRD pattern for solids formed by calcinations of uranyl oxalate at $400^{\circ} \mathrm{C}$ in air sweep gas

$20 \mathrm{XRD}$ pattern for solids formed by calcinations of uranyl oxalate at $600^{\circ} \mathrm{C}$ in air sweep gas

21 Photograph of material calcined in $\mathrm{He}$ at $400^{\circ} \mathrm{C}$ and $600^{\circ} \mathrm{C}$ from uranyl oxalate.........

22 XRD pattern for solids formed by calcinations of uranyl oxalate at $400^{\circ} \mathrm{C}$ in $\mathrm{He}$ sweep gas

$23 \mathrm{XRD}$ pattern for solids formed by calcinations of uranyl oxalate at $600^{\circ} \mathrm{C}$ in $\mathrm{He}$ sweep gas

24 Photograph of material calcined in $4 \% \mathrm{H}_{2} / 96 \% \mathrm{He}$ at $400^{\circ} \mathrm{C}$ and $600^{\circ} \mathrm{C}$ from uranyl oxalate

$25 \mathrm{XRD}$ pattern for solids formed by calcinations of uranyl oxalate at $400^{\circ} \mathrm{C}$ in $4 \%$ $\mathrm{H}_{2} / 96 \%$ He sweep gas.....

26 XRD pattern for solids formed by calcinations of uranyl oxalate at $600^{\circ} \mathrm{C}$ in $4 \%$ $\mathrm{H}_{2} / 96 \%$ He sweep gas

27 TGA results from analysis of uranyl oxalate 


\section{TABLES}

1 Concentrations of gases collected from evaporation of UNH/nitric acid.................. 11

2 Characteristics of the products of UNH calcinations.......................................... 13

3 Concentrations of gases collected from calcinations of UNH solids......................... 17

4 Concentrations of gases collected from evaporation and precipitation of uranyl

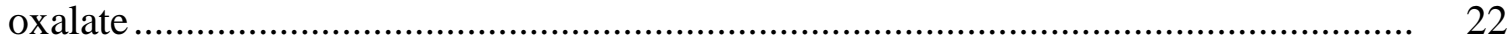

$5 \quad$ Characteristics of solid products of uranyl oxalate calcinations.............................. 23

$6 \quad$ Concentrations of gases collected from calcinations of uranyl oxalate solids............. 30

$7 \quad$ Primary products of calcinations reactions ....................................................... 33 
This page intentionally left blank 


\title{
GAS GENERATION DURING WASTE TREATMENT OF ACIDIC SOLUTIONS FROM THE DISSOLUTION OF IRRADIATED LEU TARGETS FOR ${ }^{99}$ MO PRODUCTION
}

\begin{abstract}
The goal of the Reduced Enrichment for Research and Test Reactors Program is to limit the use of high-enriched uranium (HEU) in research and test reactors by substituting low-enriched uranium (LEU) wherever possible. The work reported here documents our work to develop the calcining technologies and processes that will be needed for ${ }^{99}$ Mo production using LEU foil targets and the Modified Cintichem Process.

The primary concern with the conversion to LEU from HEU targets is that it would result in a five- to six-fold increase in the total uranium. This increase results in more liquid waste from the process. We have been working to minimize the increase in liquid waste and to minimize the impact of any change in liquid waste. Direct calcination of uranium-rich nitric acid solutions generates $\mathrm{NO}_{2}$ gas and $\mathrm{UO}_{3}$ solid.

We have proposed two processes for treating the liquid waste from a Modified Cintichem Process with a LEU foil. One is an optimized direct calcination process that is similar to the process currently in use. The other is a uranyl oxalate precipitation process. The specific goal of the work reported here was to characterize and compare the chemical reactions that occur during these two processes. In particular, the amounts and compositions of the gaseous and solid products were of interest. A series of experiments was carried out to show the effects of temperature and the redox potential of the reaction atmosphere. The primary products of the direct calcination process were mixtures of $\mathrm{U}_{3} \mathrm{O}_{8}$ and $\mathrm{UO}_{3}$ solids and $\mathrm{NO}_{2}$ gas. The primary products of the oxalate precipitation process were mixtures of $\mathrm{U}_{3} \mathrm{O}_{8}$ and $\mathrm{UO}_{2}$ solid and $\mathrm{CO}_{2}$ gas. Higher temperature and a reducing atmosphere tended to favor quadrivalent over hexavalent uranium in the solid product. These data will help producers to decide between the two processes. In addition, the data can be used to design appropriate off-gas systems for pilot and production facilities.
\end{abstract}




\section{INTRODUCTION}

\subsection{BACKGROUND}

To address nuclear proliferation concerns, the U.S. Reduced Enrichment for Research and Test Reactors (RERTR) Program is working to reduce the use of high-enriched uranium (HEU) in small-scale reactors by substituting low-enriched uranium (LEU) fuel and targets. Production of ${ }^{99} \mathrm{Mo}$ by irradiation of HEU targets accounts for a significant fraction of U.S. HEU exports. Radioactive decay of ${ }^{99}$ Mo produces ${ }^{99 \mathrm{~m}} \mathrm{Tc}$ (half-life of 2.75 days), which is used in large quantities in nuclear medicine. Thermal neutron fission of ${ }^{235} \mathrm{U}$ generates ${ }^{99} \mathrm{Mo}$; the ${ }^{235} \mathrm{U}$ is generally in the form of HEU (93\%-enriched $\left.{ }^{235} \mathrm{U}\right)$ targets. Because LEU contains $<20 \%{ }^{235} \mathrm{U}$, a five- to six-fold increase in the total amount of uranium is needed to produce an equivalent amount of ${ }^{99} \mathrm{Mo}$. Such an increase in total uranium would lead to an increase in the amount of waste, and possibly a reduction in production rate. Argonne's role is to help producers to minimize the negative impact of LEU conversion on their process.

The effluent from the initial ${ }^{99}$ Mo purification column contains most of the fission products with the uranium in nitric acid. This waste solution can be calcined to form a stable uranium oxide waste storage form. The concentration of uranium in the ion-exchange effluent, and perhaps its volume, will be higher in an LEU- than HEU-based process. The main objective of this work is to minimize the impact of the LEU waste solution on the efficiency and reliability of ${ }^{99}$ Mo production.

Our studies of the direct calcination and oxalate precipitation of the LEU waste solution address two issues: (1) the sequence of reactions that occurs during these processes and (2) the composition of the gaseous and solid products generated under various process conditions. These studies are aimed at providing data to design off-gas, waste treatment, and waste storage facilities to deal with LEU conversion. An earlier report [BAKEL-2016] provides additional information on the calcination experiments.

\subsection{GOAL}

The work reported here is aimed at providing data to decide on which process, direct calcination or oxalate precipitation, would be best for a producer and to assess the off-gas, waste treatment, and waste storage facilities needed for an LEU-based process. 


\section{EXPERIMENTAL}

\subsection{TEST MATRIX}

Our studies of both direct calcination and oxalate precipitation were done in two steps: (1) evaporation and precipitation in a glass calciner at low temperature $\left(<200^{\circ} \mathrm{C}\right)$ and $(2)$ calcination at high temperature $\left(400^{\circ} \mathrm{C}\right.$ and $\left.600^{\circ} \mathrm{C}\right)$. Separate experiments were carried out with air and $4 \% \mathrm{H}_{2} / 96 \% \mathrm{He}$ as the sweep gases. A third set of experiments was carried out with the oxalate precipitation process, using $\mathrm{He}$ as the sweep gas. The gas flow was about $1 \mathrm{~L}$ per minute.

Evaporation and precipitation experiments were performed in a glass calciner apparatus (Figure 1) that allows for direct observation of the reactions. Direct observation allowed us to determine the sequence and timing of the reactions and to understand the cause of the splattering that had previously been observed. In addition, the calciner was designed to allow collection of solid and gas samples during the experiments.

In the direct calcination studies, uranyl nitrate hexahydrate/nitric acid ( $\left.\mathrm{UNH} / \mathrm{HNO}_{3}\right)$ solutions were pumped directly into a vessel heated to between $100^{\circ} \mathrm{C}$ and $200^{\circ} \mathrm{C}$. These solutions (300 $\mathrm{g} \mathrm{U} / \mathrm{L}$ and $1 \mathrm{M} \mathrm{HNO}_{3}$ ) were similar to those expected as waste from a process using LEU targets. Water and nitric acid were evaporated, but the temperature was controlled to prevent decomposition of UHN. After the feed was stopped, a pool of molten UNH formed in the bottom of the vessel. To minimize decomposition of the UNH, the heat was removed from the vessel as soon as it appeared to be dry.

In the oxalate precipitation studies, the $\mathrm{UNH} / \mathrm{HNO}_{3}$ solutions were pumped into a heated vessel that contained solid oxalic acid. The temperature was initially below $150^{\circ} \mathrm{C}$; this relatively low temperature minimized the decomposition of oxalic acid. After the feed was stopped, the last of the water and nitric acid evaporated, leaving a cake of uranyl oxalate in the bottom of the vessel. To minimize decomposition of the uranyl oxalate, the heat was removed from the vessel as soon as it appeared to be dry.

The calcination experiments were performed in the steel calciner apparatus to allow for operation at temperatures up to $1000^{\circ} \mathrm{C}$. In addition, the calciner was designed to allow collection of gas samples during the experiment. The solid UNH or uranyl oxalate collected from the evaporation and precipitation experiments was placed in a 10 -mL beaker, which was placed in the vessel and heated to either $400^{\circ} \mathrm{C}$ or $600^{\circ} \mathrm{C}$. The beaker allowed for easy recovery of the calcined solids. Gas samples were collected throughout the experiment as the material was heated. Gas samples were also collected after the final temperature was reached. The final temperature was held for 2 hours to assure that the reactions were complete. 


\subsection{GLASS EVAPORATOR/PRECIPITATOR}

\subsubsection{Equipment}

An all-glass system (Figure 1) was built to allow direct observation of the evaporation and precipitation reactions. Direct observation of the reactions was desirable so that the evaporation of the water and nitric acid could be seen, and the heater could be turned off as soon as the evaporation was complete. This kept the temperature low enough to prevent the solids from decomposing.

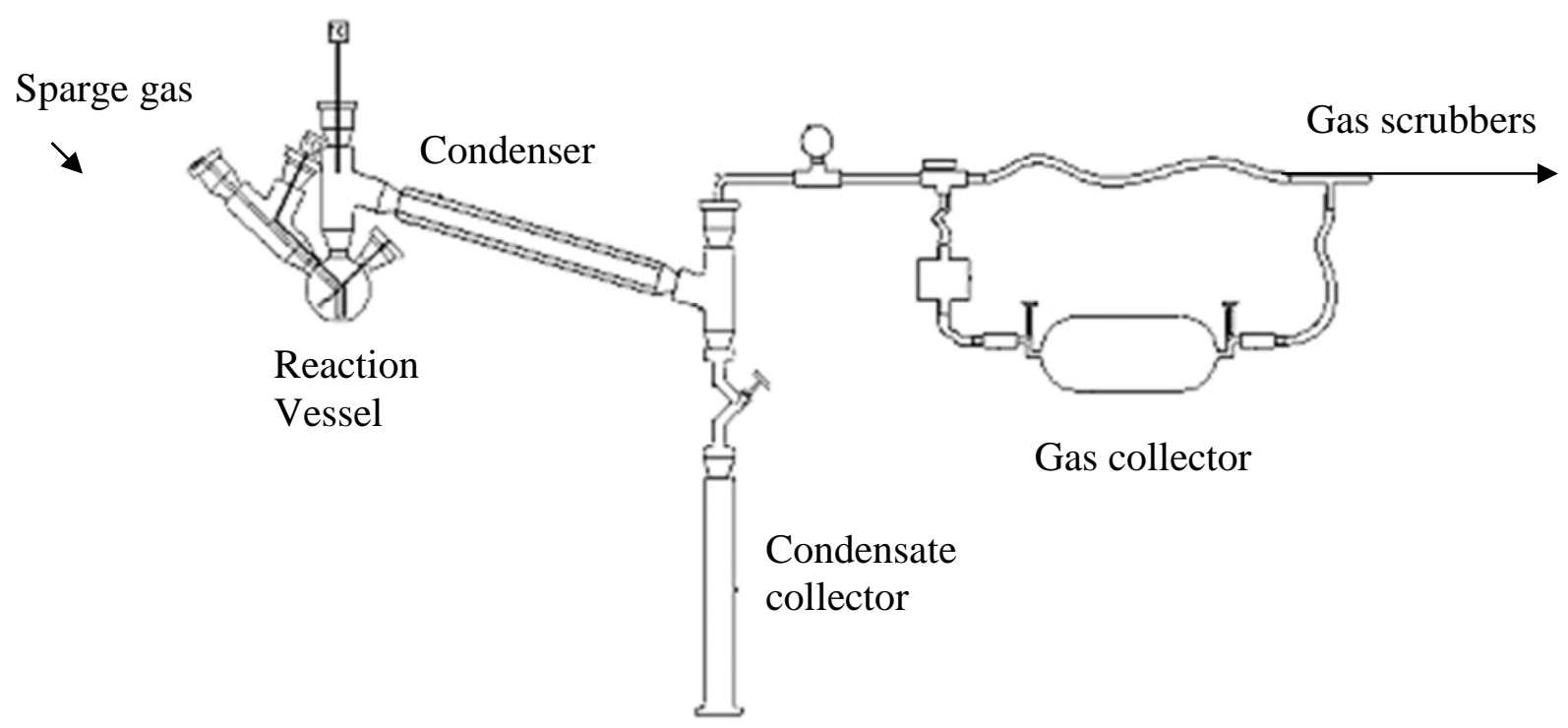

FIGURE 1 Schematic of all-glass calciner apparatus built in our laboratory to study reactions in direct calcination and oxalate processes

The calciner consisted of a 500-mL round bottom flask connected to a condenser. The flask was equipped with two thermocouples, a sparge gas line, a liquid input line, and a port to allow for sampling the liquid or slurry in the flask. The condensed liquid was collected in a graduated cylinder, allowing us to measure the condensation rate. During operation, the liquid input rate was matched to the condensation rate to maintain a volume balance. The design of the glass calciner also allowed us to collect gas samples after the water and nitric acid had been removed by condensation. These samples were collected at a few pounds per square inch gage above ambient pressure in glass bulbs. The gases that were not collected were routed to a base scrubber to neutralize the $\mathrm{NO}_{\mathrm{x}}$ gases. 


\subsubsection{Procedure}

For the direct calcinations process, depleted uranyl nitrate solutions ( $<4 \mathrm{~L}, 1000 \mathrm{~g}$ U/L) were pumped ( $<100 \mathrm{~mL} / \mathrm{min}$ ) into the $500-\mathrm{mL}$ round bottom flask. During this time, the temperature was $<100^{\circ} \mathrm{C}$. As the temperature increased, water and $\mathrm{HNO}_{3}$ were evaporated, condensed, and collected. At the same time, solid UNH was formed in the flask. Several gas samples were collected during the experiment. Once the liquid feed was stopped, the last of the liquid evaporated, and a pool of molten UNH was formed. The heater was removed from the vessel before the temperature could reach the decomposition temperature of $\mathrm{UNH}\left(250^{\circ} \mathrm{C}\right)$.

For the oxalate precipitation process, depleted uranyl nitrate solutions ( $<4 \mathrm{~L}, 1000 \mathrm{~g} \mathrm{U} / \mathrm{L}$ ) were pumped $(<100 \mathrm{~mL} / \mathrm{min})$ into the heated $500-\mathrm{mL}$ round bottom flask containing solid oxalic acid. During this time, the temperature was $<100^{\circ} \mathrm{C}$. As the temperature increased, water and $\mathrm{HNO}_{3}$ were evaporated, condensed, and collected. At the same time, solid uranyl oxalate was formed in the flask. Several gas samples were collected during the experiment. Once the liquid feed was stopped, the last of the liquid evaporated, and a cake of uranyl oxalate was formed. The heater was immediately removed from the vessel to prevent the decomposition of uranyl oxalate.

\subsection{STEEL CALCINER}

\subsubsection{Equipment}

The stainless steel calciner designed and built in our laboratory for this study was based on our understanding of the calciners/evaporators currently in use. While our system was not meant to be a scale model of that system, the basic design was similar. The stainless steel calciner used in this study is shown schematically in Figure 2. Figures 3 and 4 show details of the calciner cup and calciner head, respectively.

The calciner consisted of a steel cup (Figure 3) that was screwed into the calciner head (Figure 4) and was removed after each experiment for inspection. The calciner head was attached to the furnace and a water-cooled condenser. The condensed liquid was collected and its volume was measured, allowing us to calculate a condensation rate. During operation, the liquid input rate was matched to the condensation rate to maintain a volume balance. The design of the steel calciner also allowed us to collect gas samples after the water and nitric acid had been removed by condensation. These samples were collected at a few pounds per square inch gage above ambient pressure in glass bulbs. The gases that were not collected were routed to a base scrubber to neutralize the $\mathrm{NO}_{\mathrm{x}}$ gases. 


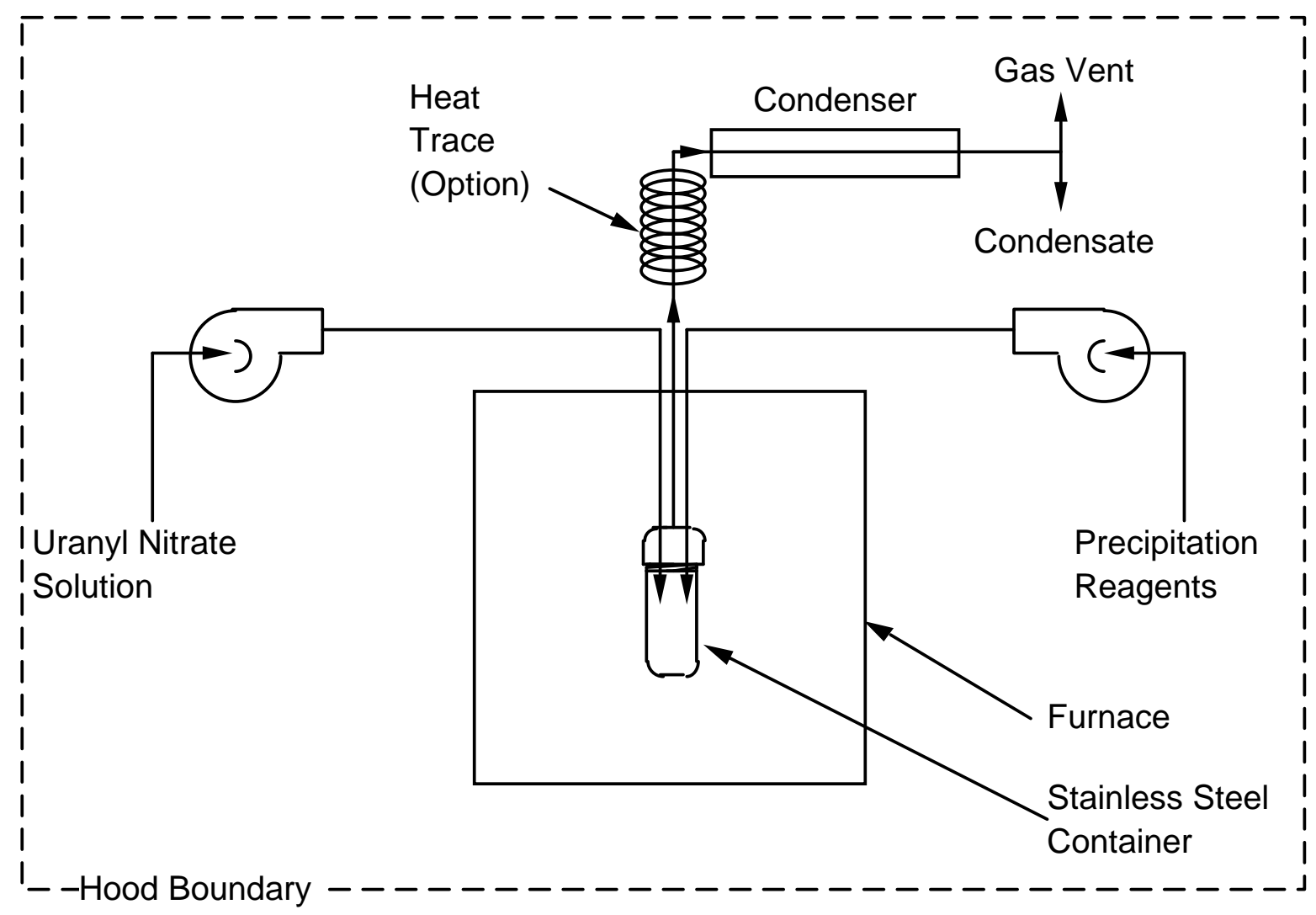

FIGURE 2 Schematic of stainless steel calciner

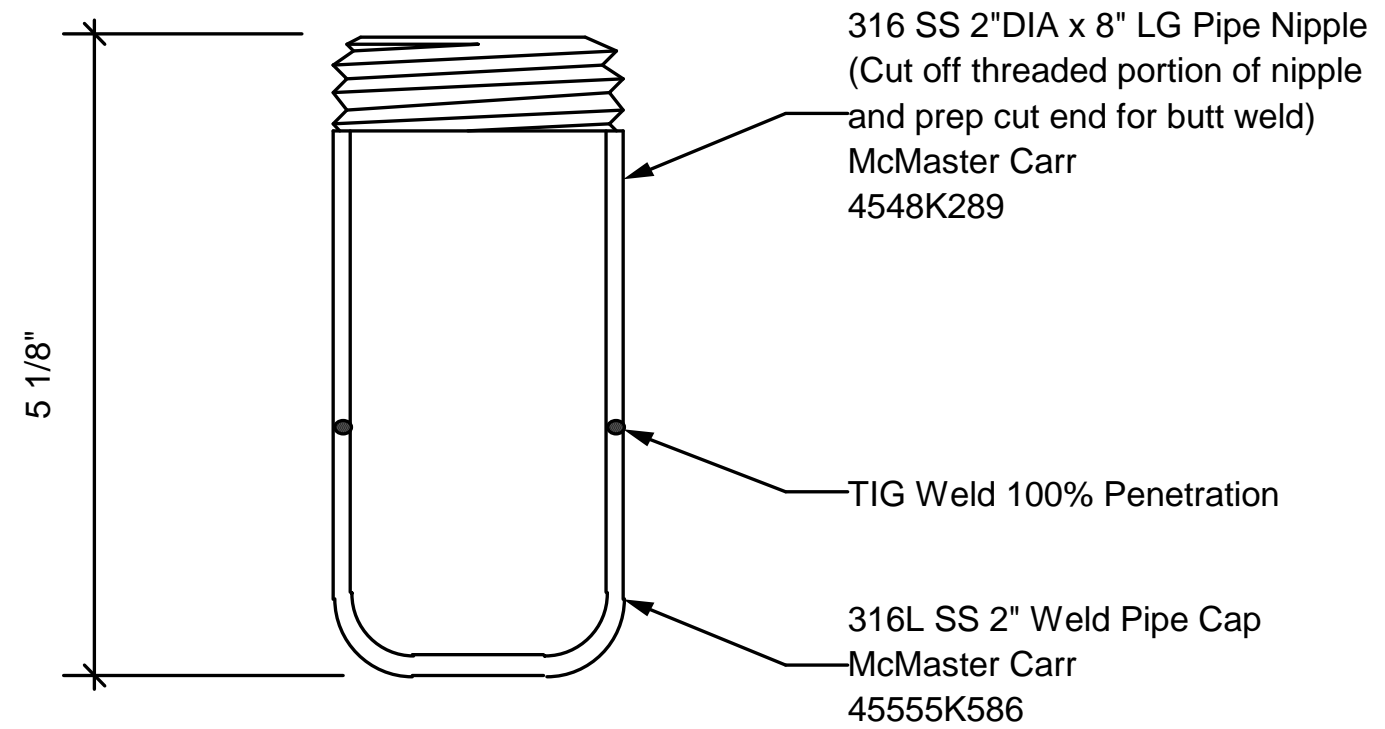

FIGURE 3 Schematic of stainless steel container in stainless steel calciner 


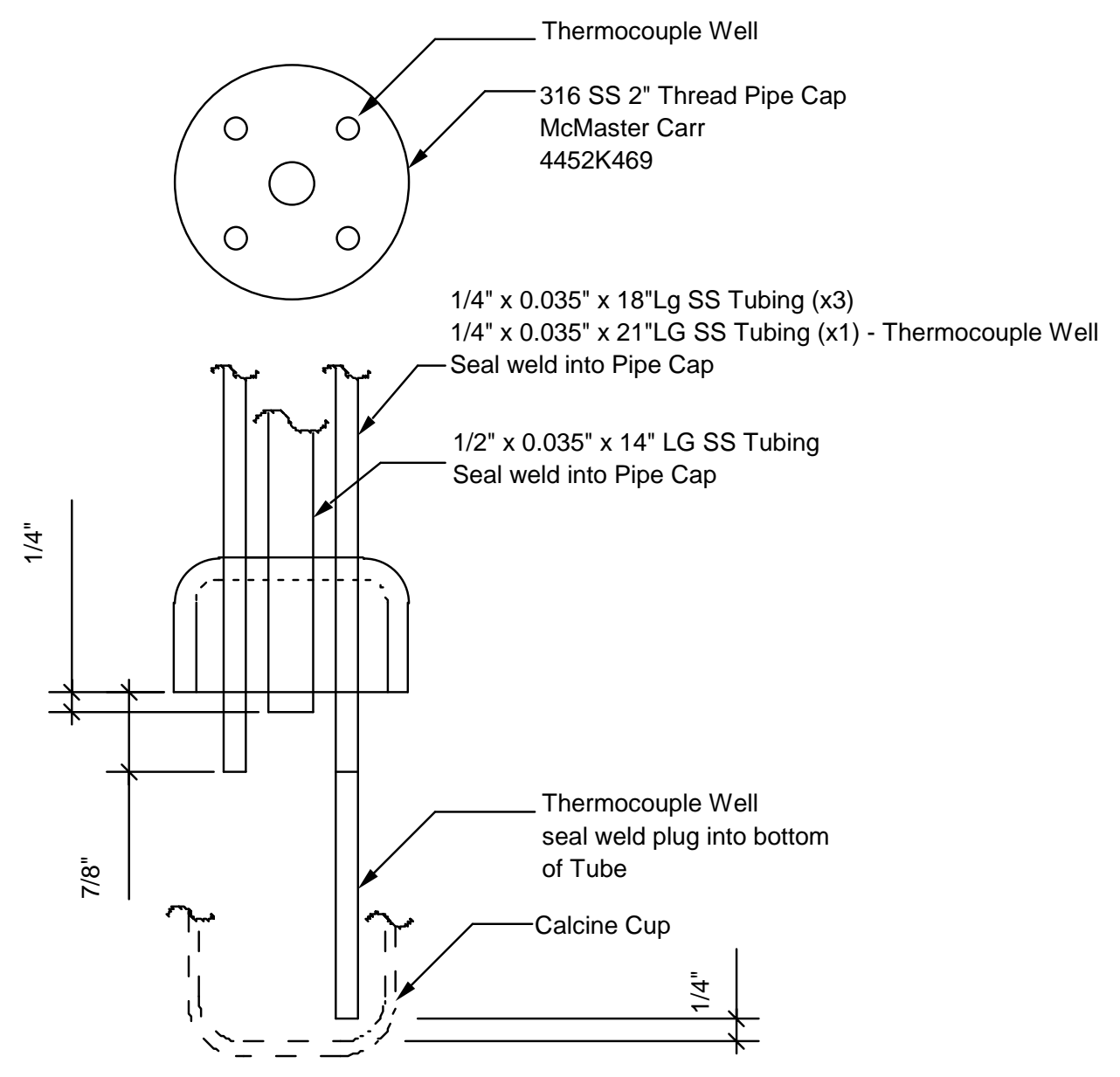

FIGURE 4 Schematic of calciner head for stainless steel calciner

\subsubsection{Procedure}

A weighed amount of solid UNH or uranyl oxalate recovered from the evaporation/precipitation processes was placed in a $10-\mathrm{mL}$ beaker. The beaker was placed in the calciner cup. Use of the beakers allowed us to easily recover the small amount of uranium oxide product from the experiments. These experiments were carried out at $400^{\circ} \mathrm{C}$ and $600^{\circ} \mathrm{C}$ in the same sweep gases that were used in the evaporation/precipitation experiments. Gas samples were collected during the experiment for analysis. The final temperatures were held for at least 2 hours to assure completion of the reaction.

\subsection{GAS ANALYSIS}

The gas samples collected during the evaporation/precipitation and calcinations were analyzed with a mass spectrometer designed specifically for gas analysis. The gas samples were introduced though a capillary tube into the ionization source. The fragments were separated 
using a quadrupole. The fragments were assigned as follows: $\mathrm{CO}+\mathrm{N}_{2}, \mathrm{~m} / \mathrm{z}=28(\mathrm{~m} / \mathrm{z}$ is the value of a fragment's mass divided by its charge). The $\mathrm{CO}$ cannot be determined in the samples collected with air as the sparge gas, where $\mathrm{NO}, \mathrm{m} / \mathrm{z}=30 ; \mathrm{O}_{2}, \mathrm{~m} / \mathrm{z}=32 ; \mathrm{CO}_{2}+\mathrm{N}_{2} \mathrm{O}, \mathrm{m} / \mathrm{z}=44$; and $\mathrm{NO}_{2}, \mathrm{~m} / \mathrm{z}=46$. The $\mathrm{m} / \mathrm{z}=44$ peak was assigned to $\mathrm{N}_{2} \mathrm{O}$ in the $\mathrm{UNH}$ tests and to $\mathrm{CO}_{2}$ in the oxalate tests.

\subsection{THERMOGRAVIMETRIC ANALYSIS}

Samples (UNH and uranyl oxalate solids) collected from the evaporation/precipitation steps were analyzed by thermogravimetric analyses (TGA). These analyses characterize the thermal decomposition of solid phases. Mass loss was monitored as a function of increasing temperature, and the evolved gas was identified by analysis of the infrared absorption line energies. These data were used to assist in identifying the gaseous products of the calcination of UNH and uranyl oxalate.

The instrument used in this study was manufactured by Netzsch, and has a Fourier transform infrared (FTIR) spectrometer connected to the gas outlet. The entire unit is located in a glovebox. A buoyancy correction was run in an empty alumina crucible with a lid. Air was used to purge the balance chamber and the furnace cavity for the glovebox. The balance purge gas a flow rate was $15 \mathrm{~mL} / \mathrm{min}$. The furnace gas flow rate was $60 \mathrm{~mL} / \mathrm{min}$. These flows were combined in the furnace. The total air flow was $65 \mathrm{~mL} / \mathrm{min}$.

The FTIR measurements were obtained with a Mattson Galaxy series FTIR equipped with a deuterated triglycine sulfate (DTGS) detector and a 10-cm path length gas cell (Harrick Industries). The outlet of the TGA furnace was connected to a high efficiency filter (Mott Industries) by approximately $3 \mathrm{ft}$ of stainless steel tubing (1/8-in. OD). The outlet of the filter was connected to the FTIR cell by $10 \mathrm{ft}$ of Teflon tubing (1/8-in. OD). The cell was equipped with anti-reflection coated $\mathrm{ZnSe}$ windows (1-ft dia., 1/8-in. thick). Kalrez O-ring compression seals were used to seal the windows to the cell body. The internal volume of the cell was $22 \mathrm{~cm}^{3}$. Infrared (IR) absorption bands were identified with the Hanst gas phase IR reference spectra [HANST-1990]. 


\section{RESULTS AND DISCUSSION}

\subsection{DIRECT CALCINATION PROCESS}

In earlier work, an experiment was conducted to determine how much uranium could be placed into one calciner cup. That amount was determined to be $675 \mathrm{~g}$ U. The in-cup density was about $3.0 \mathrm{~g} \mathrm{U} / \mathrm{mL}$. At the end of the experiment, solid UNH and uranium oxide had splattered up the sides of the cup as well as onto the calciner head. This splattering was a concern because of possible equipment contamination in a production facility.

\subsubsection{Evaporation/Precipitation}

In the present work, experiments were performed in the glass calciner apparatus shown in Figure 1, which allowed collection of solid and gas samples during the evaporation and precipitation of UNH. Different sparge gases (air and $4 \% \mathrm{H}_{2} / 96 \% \mathrm{He}$ ) were used to show the effect of redox potential on the reactions; air was used because it is highly oxidizing, and $4 \%$ $\mathrm{H}_{2} / 96 \% \mathrm{He}$ was used because it is reducing. Analysis results are given below.

\subsubsection{Solids}

The crystalline solids generated during the evaporation/precipitation experiments had the typical bright yellow color of UNH. The solids were analyzed with X-ray diffraction (XRD) to confirm their crystalline structure. All of the solids formed during evaporation of $\mathrm{UNH} / \mathrm{HNO}_{3}$ solutions were identified as $\mathrm{UO}_{2}\left(\mathrm{NO}_{3}\right)_{2} \bullet 3 \mathrm{H}_{2} \mathrm{O}$ by their XRD patterns, regardless of the sparge gas used (Figures 5-7). The trihydrate is known to precipitate from concentrated $\mathrm{HNO}_{3}$ solutions.

\subsubsection{Gases}

Gas samples were collected during the evaporation/precipitation experiments and were analyzed for nitrogen and carbon oxide gases. Table 1 shows the results of the gas analyses. The mass spectrometer used for detection of gases in this analysis was unable to distinguish $\mathrm{CO}_{2}$ from $\mathrm{N}_{2} \mathrm{O}$. In these experiments, no $\mathrm{CO}_{2}$ is expected, so the $\mathrm{m} / \mathrm{z}=44$ peak is attributed entirely to $\mathrm{N}_{2} \mathrm{O}$.

The experiment performed with air sparge gas contained no detectable nitrogen gases, suggesting that all of the nitrogen was condensed as $\mathrm{HNO}_{3}$. The experiment performed with $4 \% \mathrm{H}_{2} / 96 \%$ He reducing sparge gas contained a small amount of $\mathrm{CO}_{2}+\mathrm{N}_{2} \mathrm{O}$ gas. 


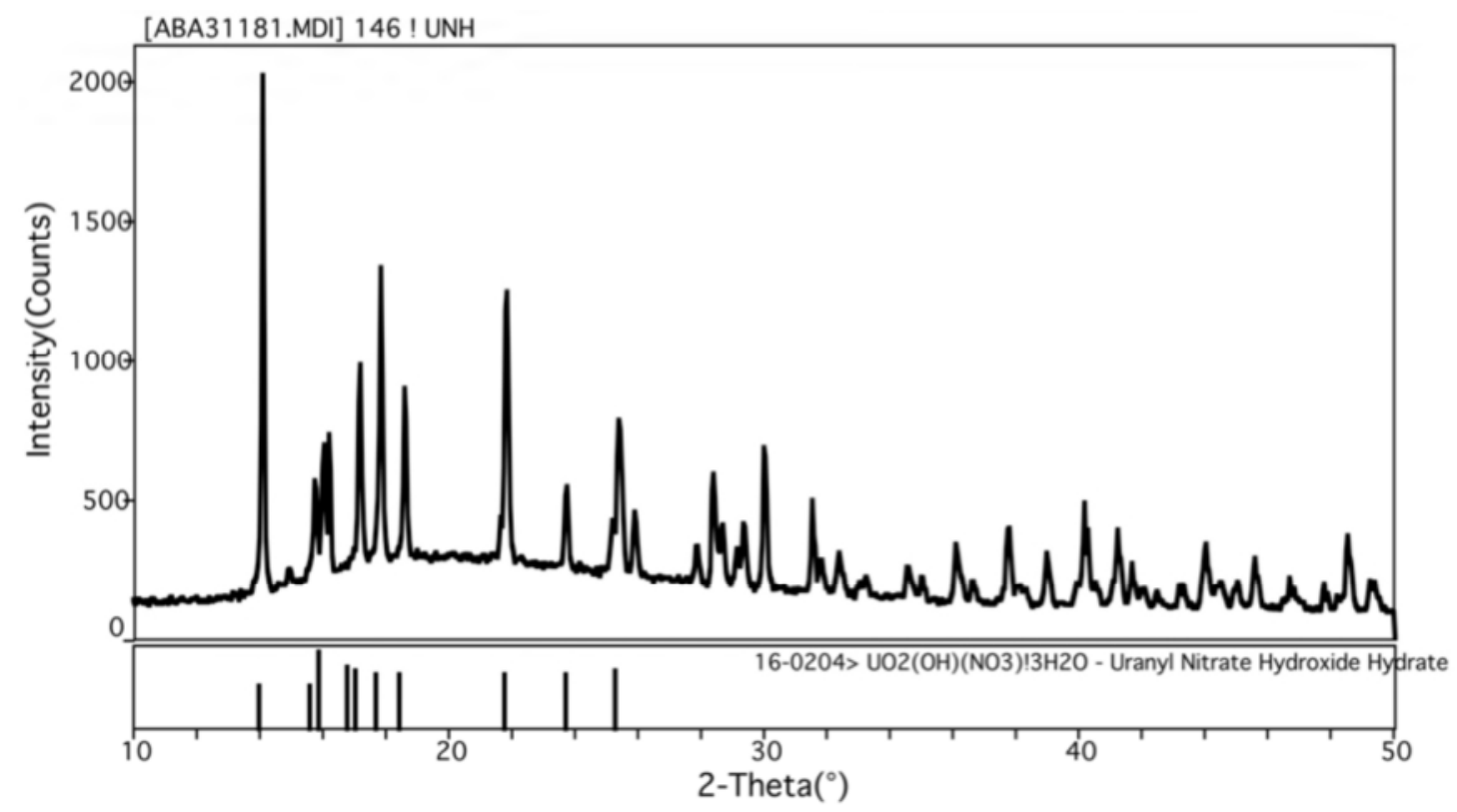

FIGURE 5 XRD pattern for solids formed by evaporation of $\mathrm{UNH} / \mathrm{HNO}_{3}$ solution with air sparge gas

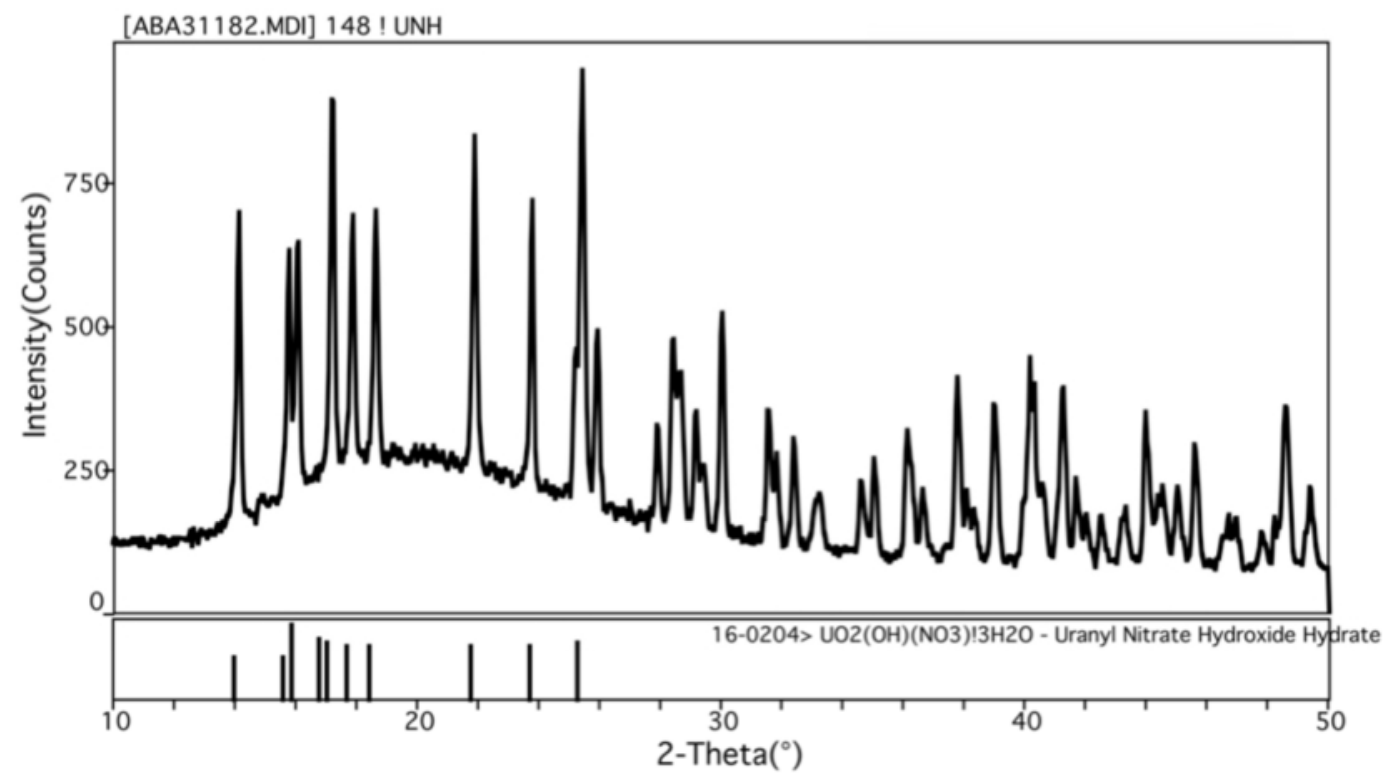

FIGURE 6 XRD pattern for solids formed by evaporation of $\mathrm{UNH} / \mathrm{HNO}_{3}$ solution with He sparge gas 


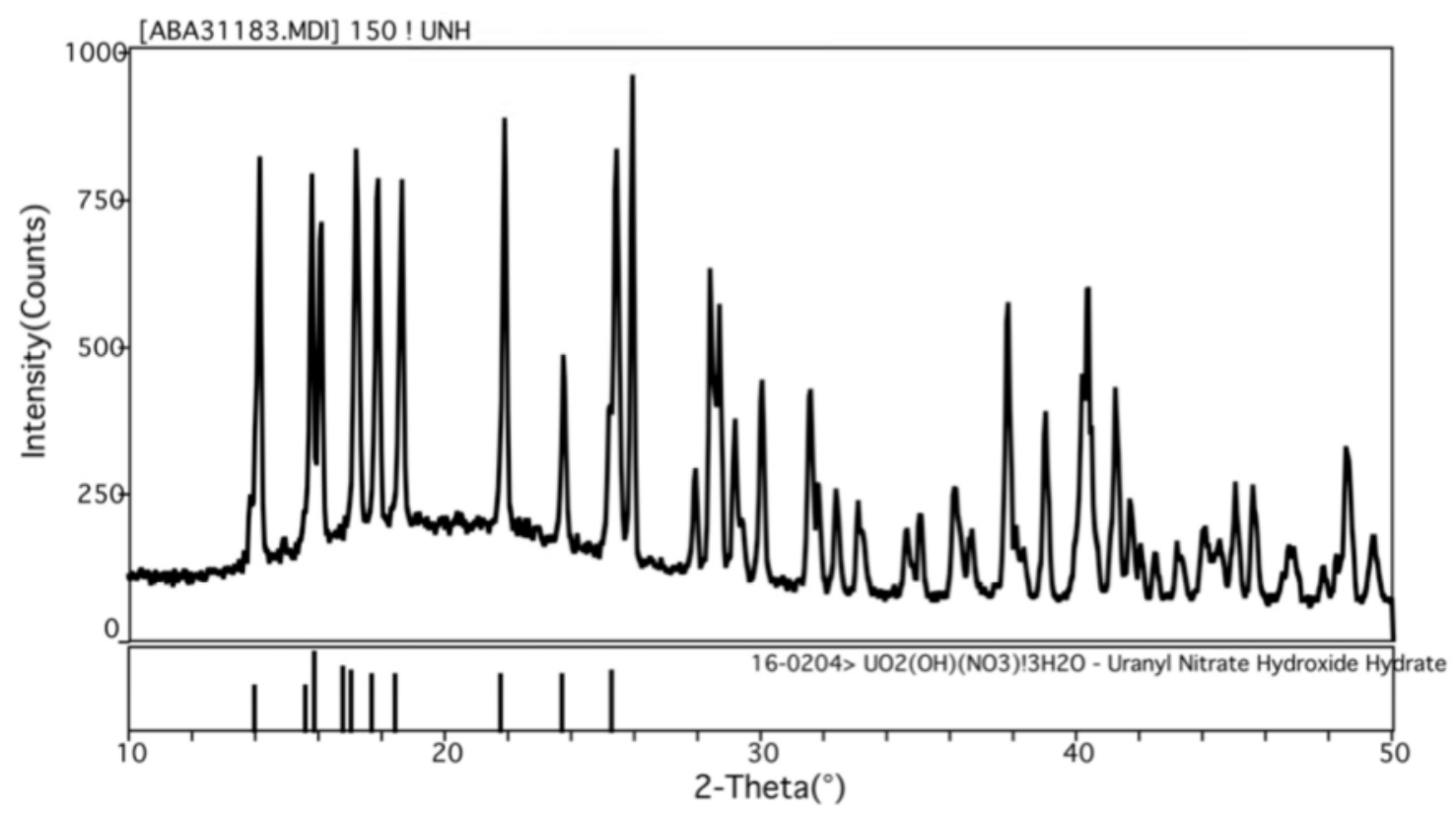

FIGURE 7 XRD pattern for solids formed by evaporation of $\mathrm{UNH} / \mathrm{HNO}_{3}$ solution with $4 \% \mathrm{H}_{2} / 96 \%$ He sparge gas

TABLE 1 Concentrations (mol\%) of gases collected from evaporation of $\mathrm{UNH} /$ nitric acid.

\begin{tabular}{lccc}
\hline & $\begin{array}{c}\mathrm{NO}_{2} \\
\mathrm{~m} / \mathrm{z}=46\end{array}$ & $\begin{array}{c}\mathrm{NO} \\
\mathrm{m} / \mathrm{z}=30\end{array}$ & $\begin{array}{c}\mathrm{CO}_{2}+\mathrm{N}_{2} \mathrm{O} \\
\mathrm{m} / \mathrm{z}=44\end{array}$ \\
\hline Time & & & \\
Air & & & \\
55 & $<0.01$ & $<0.01$ & $<0.01$ \\
76 & $<0.01$ & $<0.01$ & $<0.01$ \\
& $<0.01$ & $<0.01$ & $<0.01$ \\
$4 \% \mathrm{H}_{2}, 96 \% \mathrm{He}$ & & & \\
18 & $<0.01$ & $<0.01$ & 0.05 \\
53 & $<0.01$ & 0.01 & 0.05 \\
66 & $<0.01$ & 0.02 & 0.08 \\
\hline
\end{tabular}

a Number of minutes after furnace was turned on when sample was collected. 


\subsubsection{Reactions}

Analysis of the solids generated during the evaporation/precipitation of UNH shows that all of the uranium was in the form of UNH. Table 1 shows that no nitrogen gases were generated in the experiments with air sparge gas. On the other hand, a small amount of $\mathrm{CO}_{2}+\mathrm{N}_{2} \mathrm{O}$ was generated in the experiments with $4 \% \mathrm{H}_{2} / 96 \%$ He sparge gas. Reduction of $\mathrm{HNO}_{3}$ with hydrogen has been reported to generate ammonia (equation 1). Further, ammonia can oxidize to $\mathrm{N}_{2} \mathrm{O}$ (equation 2). Such a reaction path might generate the small amount of $\mathrm{N}_{2} \mathrm{O}$ observed. Alternatively, the $\mathrm{m} / \mathrm{z}=44$ fragment detected in the mass spectrometer might come from a small amount of $\mathrm{CO}_{2}$ contamination. The absence of $\mathrm{NO}_{2}$ from the generated gases shows that no decomposition of the UNH occurred.

$$
\begin{aligned}
& \mathrm{HNO}_{3}+\mathrm{H}_{2} \rightarrow \mathrm{NH}_{3}+3 / 2 \mathrm{O}_{2} \\
& 2 \mathrm{NH}_{3}+2 \mathrm{O}_{2} \rightarrow \mathrm{N}_{2} \mathrm{O}+3 \mathrm{H}_{2} \mathrm{O}
\end{aligned}
$$

\subsubsection{Calcinations of UNH}

The samples of UNH from the evaporation/precipitation experiments with $\mathrm{UHN} / \mathrm{HNO}_{3}$ solutions were calcined in the steel calciner. The UNH was calcined in the same atmosphere as it was evaporated. Calcinations were done at $400^{\circ} \mathrm{C}$ and $600^{\circ} \mathrm{C}$. Gaseous products were collected throughout the calcinations. The experiment was held at the final temperature for at least 2 hours to ensure complete reaction. Solids from the calcinations were photographed and analyzed by XRD to determine their compositions. Gases from the calcinations were analyzed with a mass spectrometer.

\subsubsection{Solids}

Table 2 summarizes the analyses for the solids in the UNH calcinations. The solid products of the calcinations in air at $400^{\circ} \mathrm{C}$ and $600^{\circ} \mathrm{C}$ had a yellow color typical of $\mathrm{UO}_{3}$ (Figure 8). The XRD patterns (Figures 9 and 10) show that these samples were composed primarily of $\mathrm{UO}_{3}$, but also contained some $\mathrm{U}_{3} \mathrm{O}_{8}$. The sample calcined at $600^{\circ} \mathrm{C}$ appears to have contained more $\mathrm{U}_{3} \mathrm{O}_{8}$ than the sample calcined at $400^{\circ} \mathrm{C}$, according to the XRD pattern.

The solids from the calcination in $4 \% \mathrm{H}_{2} / 96 \% \mathrm{He}$ at $400^{\circ} \mathrm{C}$ had a greenish-black color typical of $\mathrm{U}_{3} \mathrm{O}_{8}$ (Figure 11 , left side), while the material calcined at $600^{\circ} \mathrm{C}$ (Figure 11, right side) had a black color typical of $\mathrm{UO}_{2}$. The XRD pattern in Figure 12 shows that the material calcined at $400^{\circ} \mathrm{C}$ was composed primarily of $\mathrm{U}_{3} \mathrm{O}_{8}$, and contained a small amount of $\mathrm{UO}_{3}$. The XRD pattern in Figure 13 shows that the material calcined at $600^{\circ} \mathrm{C}$ was composed entirely of $\mathrm{UO}_{2}$. 
TABLE 2 Characteristics of the products of UNH calcinations

\begin{tabular}{lll}
\hline & Appearance & Identification \\
\hline & & \\
Air, $400^{\circ} \mathrm{C}$ & Yellow & $\begin{array}{l}\mathrm{U}_{3} \mathrm{O}_{8} / \mathrm{UO}_{3} \\
(28 / 72)\end{array}$ \\
& & $\mathrm{U}_{3} \mathrm{O}_{8} / \mathrm{UO}_{3}$ \\
& Yellow & $(24 / 76)$ \\
& & \\
$4 \% \mathrm{H}_{2} / 96 \% \mathrm{He}, 400^{\circ} \mathrm{C}$ & Greenish-black $60{ }^{\circ} \mathrm{C}$ & $\mathrm{U}_{3} \mathrm{O}_{8} / \mathrm{UO}_{3}$ \\
& & $(30 / 70)$ \\
$4 \% \mathrm{H}_{2} / 96 \% \mathrm{He}, 600^{\circ} \mathrm{C}$ & Black & $\mathrm{UO}_{2}$ \\
\hline
\end{tabular}

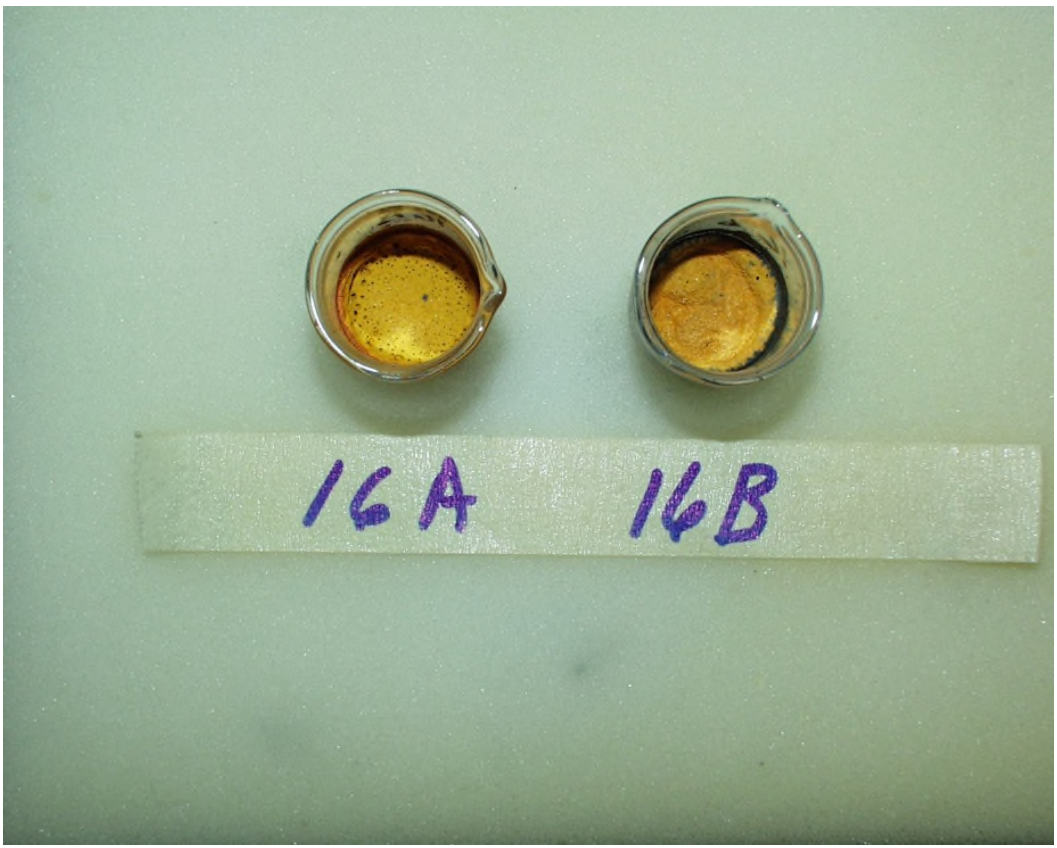

FIGURE 8 Photograph of material calcined in air at $400^{\circ} \mathrm{C}$ (left) and $600^{\circ} \mathrm{C}$ (right) from UNH experiments 


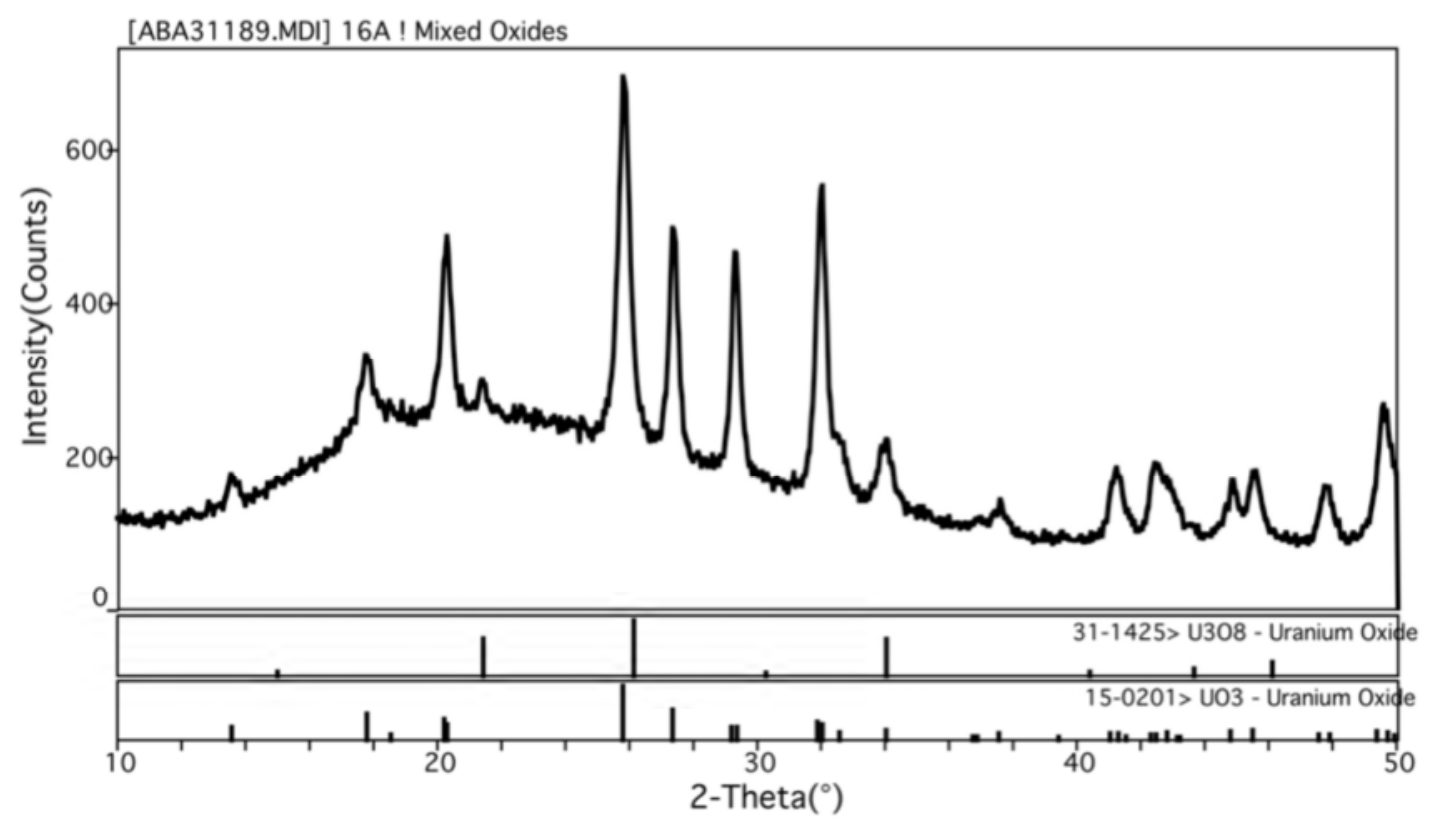

FIGURE 9 XRD pattern for solids formed by calcinations at $400^{\circ} \mathrm{C}$ of $\mathrm{UNH}$ in air sparge gas

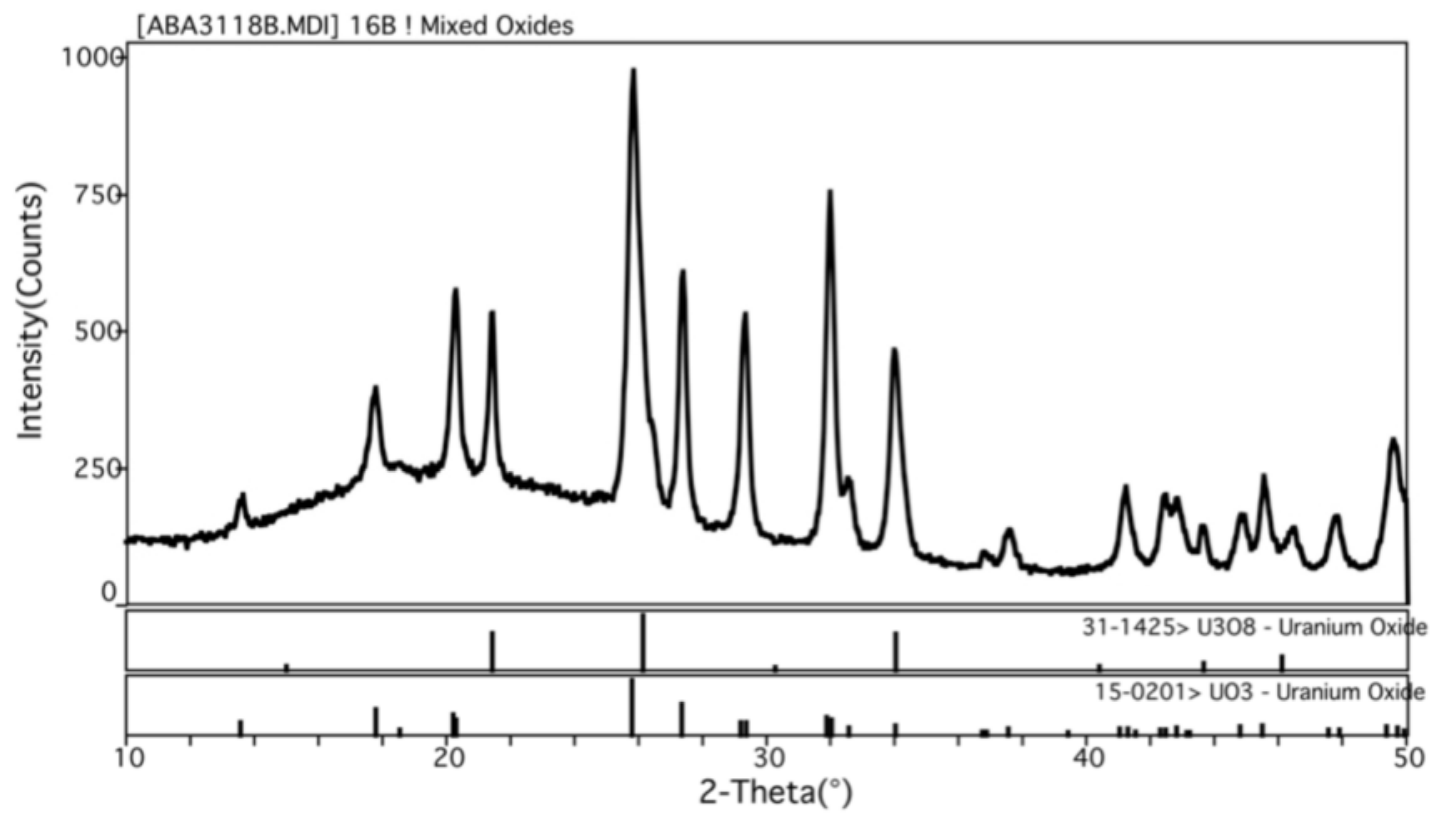

FIGURE 10 XRD pattern for solids formed by calcinations at $600^{\circ} \mathrm{C}$ of $\mathrm{UNH}$ in air sparge gas 


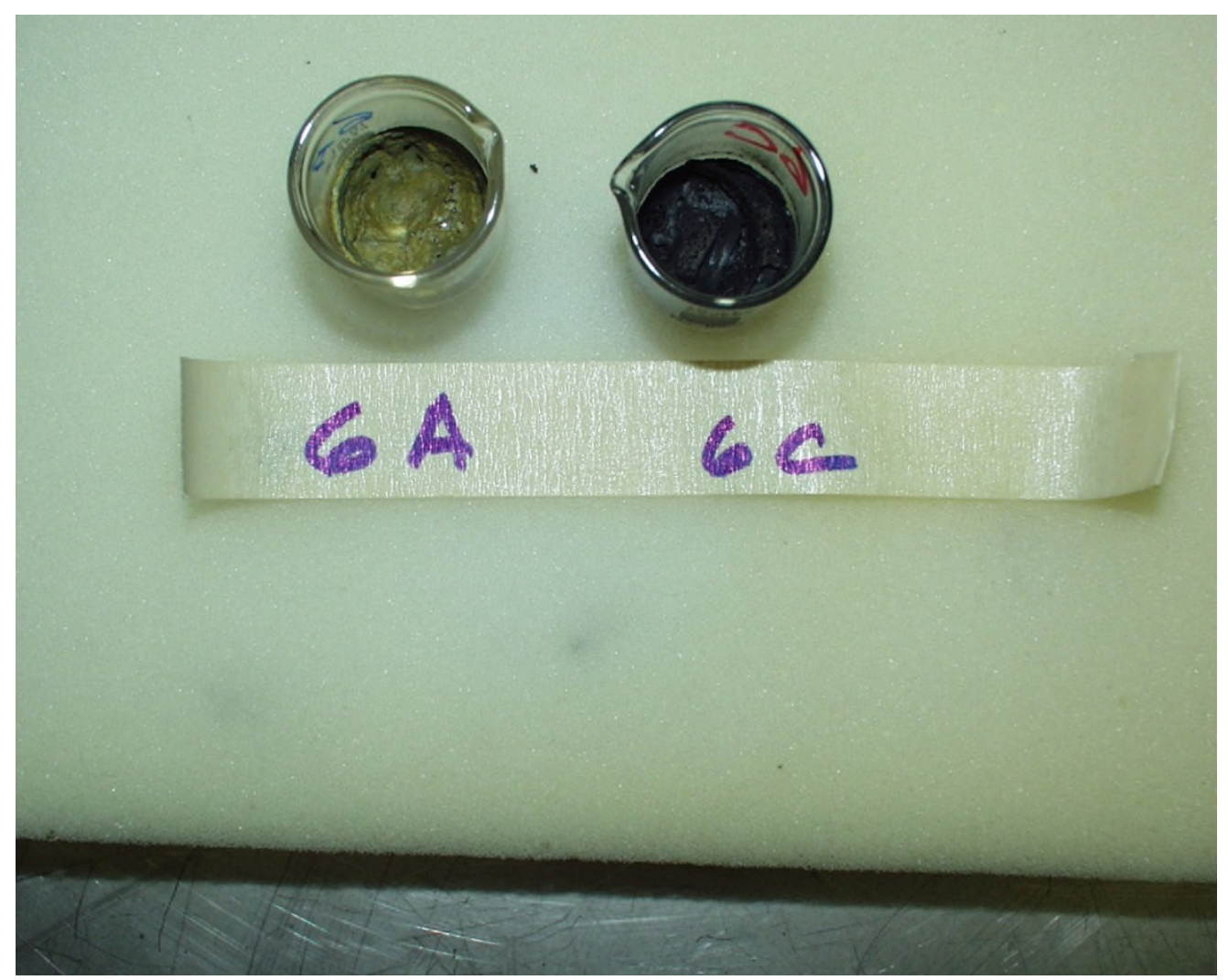

FIGURE 11 Photograph of material calcined in $4 \% \mathrm{H}_{2} / 96 \%$ He at $400^{\circ} \mathrm{C}$ (left) and $600^{\circ} \mathrm{C}$ (right) from UNH experiments

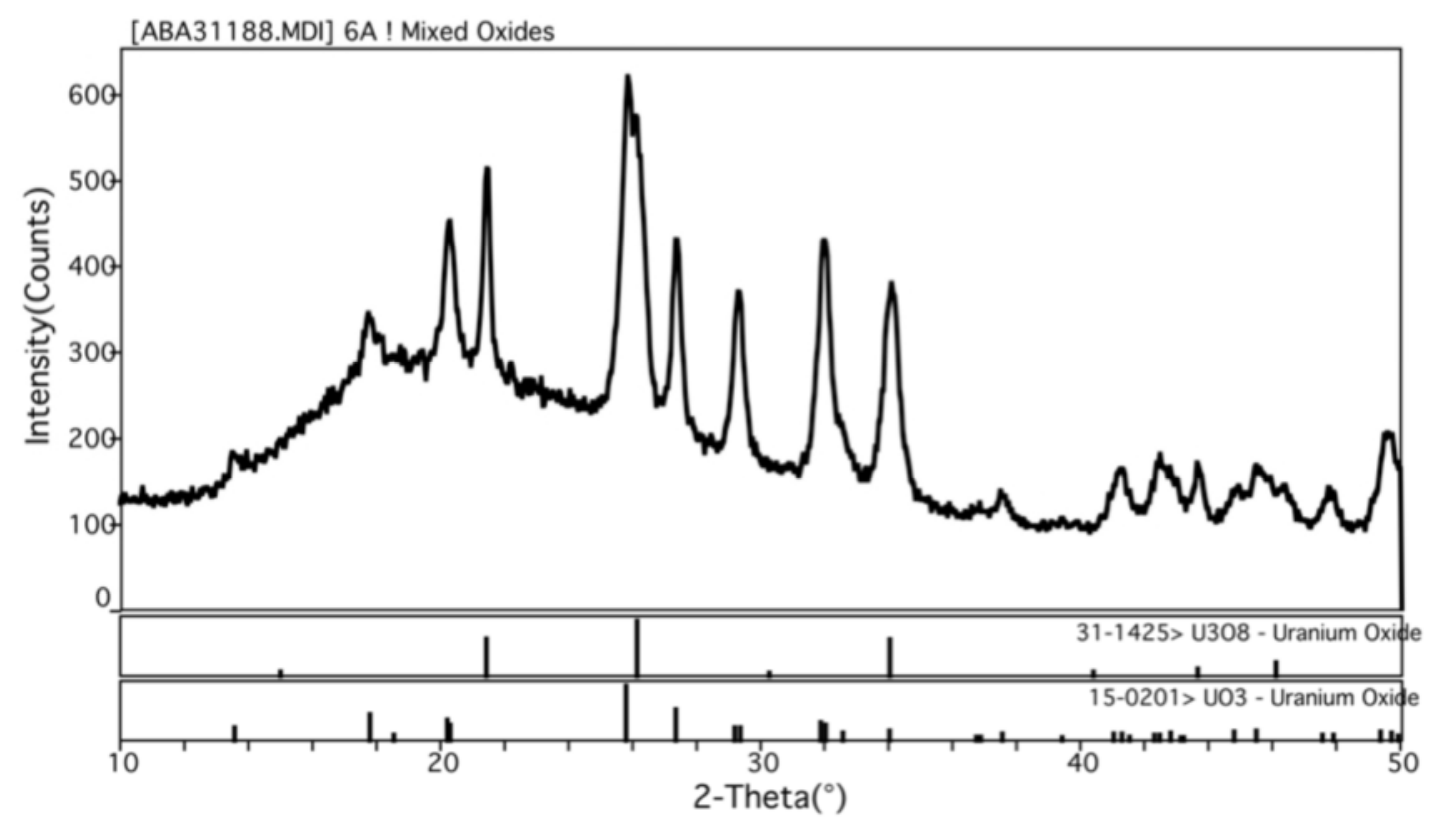

FIGURE 12 XRD pattern for solids formed by calcinations at $400^{\circ} \mathrm{C}$ of $\mathrm{UNH}$ in $4 \% \mathrm{H}_{2} / 96 \%$ He sparge gas 


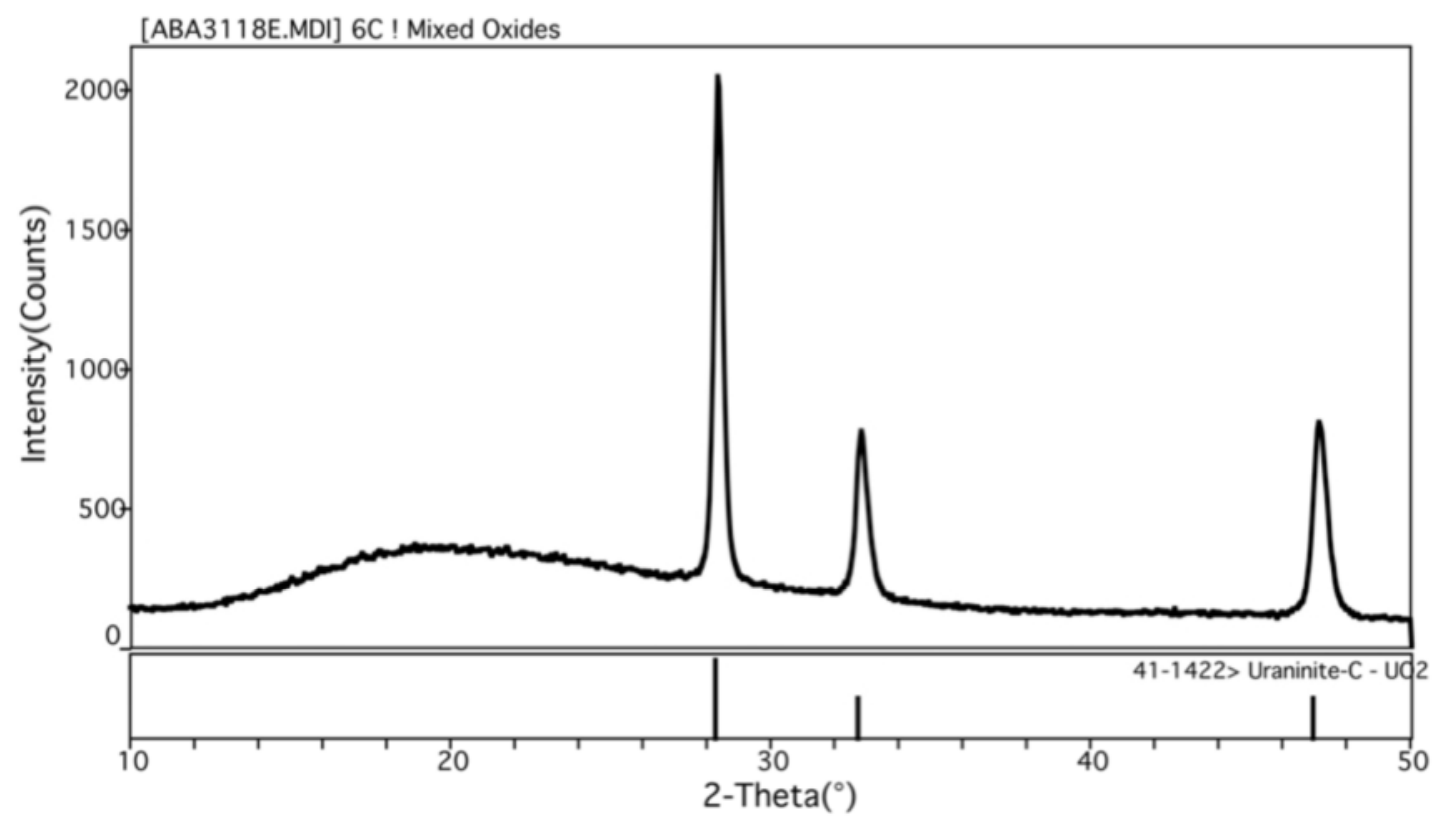

FIGURE 13 XRD pattern for solids formed by calcinations at $600^{\circ} \mathrm{C}$ of $\mathrm{UNH}$ in $4 \%$ $\mathrm{H}_{2} / 96 \%$ He sparge gas

\subsubsection{Gases}

The gas samples collected during the calcination experiments with UNH were analyzed with mass spectrometry to determine their compositions (Table 3). The experiment performed in air generated $\mathrm{NO}_{2}$, as well as smaller amounts of $\mathrm{NO}$ and $\mathrm{CO}_{2}+\mathrm{N}_{2} \mathrm{O}$. (Because the major fragment detected for either $\mathrm{CO}_{2}$ or $\mathrm{N}_{2} \mathrm{O}$ is $\mathrm{m} / \mathrm{z}=44$, the peak at $\mathrm{m} / \mathrm{z}=44$ is taken as a combination of the two gases.) The highest concentrations of nitrogen gases were observed in the samples collected at about $25 \mathrm{~min}$.

The experiment performed in $4 \% \mathrm{H}_{2} / 96 \%$ He generated $\mathrm{NO}_{2}$, as well as smaller amounts of $\mathrm{NO}$ and $\mathrm{CO}_{2}+\mathrm{N}_{2} \mathrm{O}$ (Table 3). The highest concentrations of these gases were observed in the sample collected 25 min after the beginning of the experiment. The presence of $\mathrm{NO}_{2}$ in the generated gas samples shows that denitration of the UNH occurred during the calcination experiments.

The TGA analysis was conducted with UNH collected from the evaporation/precipitation experiments. Because the TGA was run with an air purge gas, the results should compare to our calcination results in air. Figure 14 shows that the major decomposition products of the TGA evolved at $120-250^{\circ} \mathrm{C}$ and at $250-830^{\circ} \mathrm{C}$. 
TABLE 3 Concentrations (mol \%) of gases collected from calcinations of UNH solids

\begin{tabular}{lrrr}
\hline \multicolumn{1}{c}{ Time $^{\mathrm{a}}$} & $\begin{array}{c}\mathrm{NO}_{2} \\
\mathrm{~m} / \mathrm{z}=46\end{array}$ & $\begin{array}{c}\mathrm{NO} \\
\mathrm{m} / \mathrm{z}=30\end{array}$ & $\begin{array}{c}\mathrm{CO}_{2}+\mathrm{N}_{2} \mathrm{O} \\
\mathrm{m} / \mathrm{z}=44\end{array}$ \\
\hline & & & \\
Air, $400^{\circ} \mathrm{C}$ & & & \\
15 & $<0.01$ & $<0.01$ & $<0.01$ \\
21 & 0.10 & 0.01 & 0.08 \\
26 & 1.62 & 0.33 & 0.12 \\
36 & $<0.01$ & 0.04 & 0.05 \\
46 & $<0.01$ & 0.09 & 0.03 \\
56 & 0.03 & $<0.01$ & 0.07 \\
& & & \\
$\mathrm{Air}, 600^{\circ} \mathrm{C}$ & & & \\
15 & $<0.01$ & $<0.01$ & $<0.01$ \\
25 & 1.67 & 0.37 & 0.14 \\
35 & 0.22 & 0.11 & 0.04 \\
45 & $<0.01$ & 0.02 & $<0.01$ \\
$4 \% \mathrm{H}_{2} / 96 \% \mathrm{He}, 400^{\circ} \mathrm{C}$ & & & \\
15 & & & \\
25 & 0.27 & $<0.01$ & $<0.01$ \\
30 & 2.75 & 0.48 & 0.34 \\
40 & 0.24 & $<0.01$ & 0.03 \\
& 0.09 & $<0.01$ & 0.01 \\
$4 \% \mathrm{H}_{2} / 96 \% \mathrm{He}, 600^{\circ} \mathrm{C}$ & & & \\
15 & & & \\
18 & 0.26 & 0.08 & 0.07 \\
23 & 0.88 & 0.13 & 0.29 \\
27 & 0.64 & 0.13 & 0.18 \\
& 0.01 & $<0.01$ & $<0.01$ \\
\hline
\end{tabular}

a Number of minutes after furnace was turned on when sample was collected.

The TGA results are consistent with our interpretations of the calcination gas data.

Analysis of the evolved gases with FTIR shows that the first product was water, and the second was $\mathrm{NO}_{2}$. The water detected during the TGA experiments would not have been detected in our calcinations because any water evolved would have condensed. The major gaseous product of our calcinations of UNH in air sweep gas was $\mathrm{NO}_{2}$ (Table 3). Therefore, the results from the TGA are consistent with the results from the calcination experiments. Specifically, $\mathrm{NO}_{2}$ is the major gas generated during the calcination of UNH in air. 


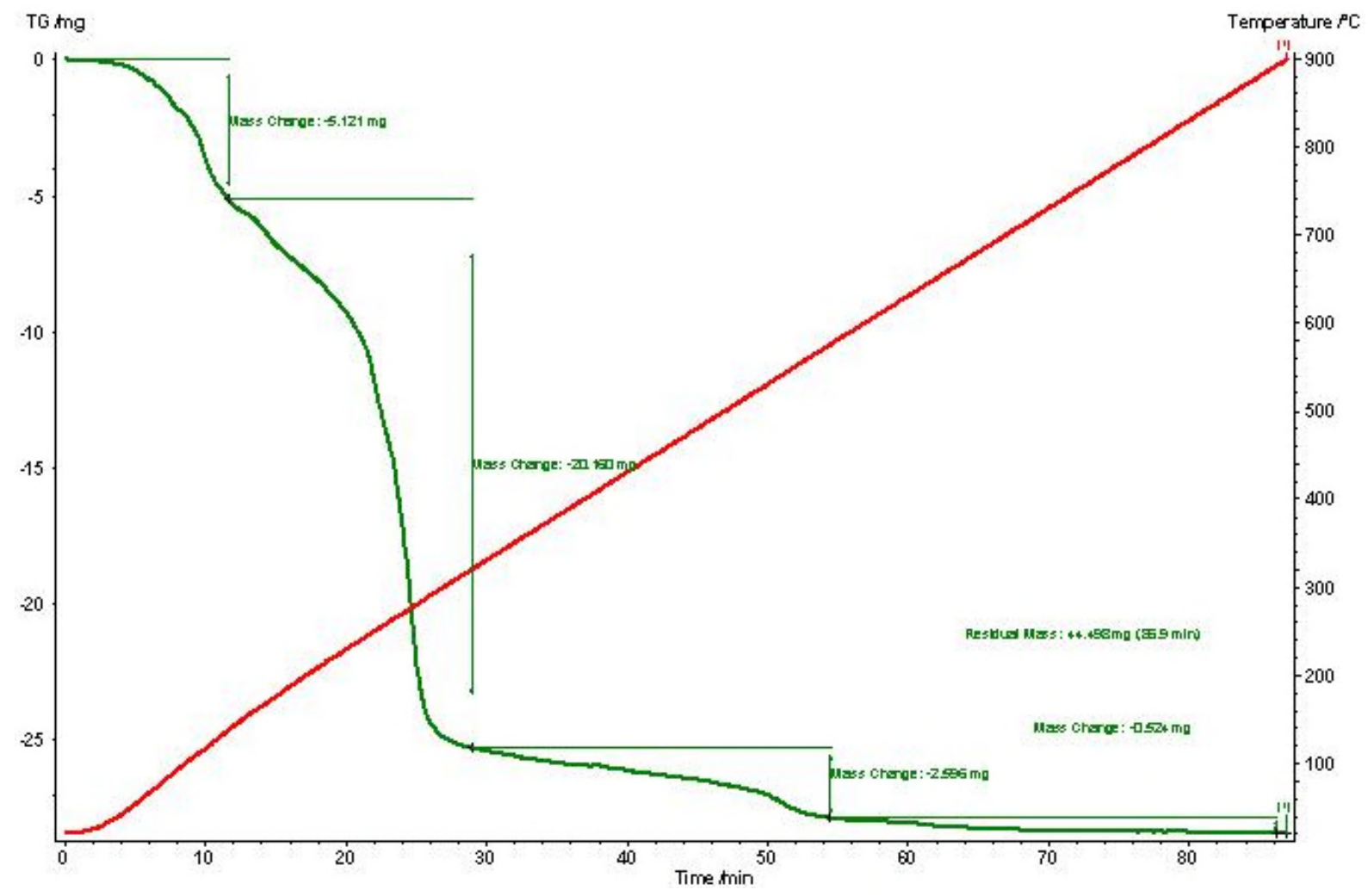

FIGURE 14 TGA results from analysis of UNH

\subsubsection{Reactions}

The calcination of UNH under these experimental conditions is a combination of several complex reactions. The present data do not allow us to rigorously determine all of the reactions, or the stoichiometry of the overall reaction. However, the products observed, and their relative abundance, allow us to propose three reactions that could occur during the calcinations:

$$
\begin{gathered}
\mathrm{UO}_{2}\left(\mathrm{NO}_{3}\right)_{2} \rightarrow \mathrm{UO}_{3}+2 \mathrm{NO}_{2}+1 / 2 \mathrm{O}_{2} \\
3 \mathrm{UO}_{3} \rightarrow \mathrm{U}_{3} \mathrm{O}_{8}+1 / 2 \mathrm{O}_{2} @ 700^{\circ} \mathrm{C} \\
\mathrm{UO}_{2}\left(\mathrm{NO}_{3}\right)_{2}+2 \mathrm{H}_{2} \rightarrow \mathrm{UO}_{2}+2 \mathrm{NO}_{2}+2 \mathrm{H}_{2} \mathrm{O}
\end{gathered}
$$

Calcination of $\mathrm{UNH}$ in air at $400^{\circ} \mathrm{C}$ yielded $\mathrm{UO}_{3}$, a small amount of $\mathrm{U}_{3} \mathrm{O}_{8}$, and $\mathrm{NO}_{2}$ gas. Therefore, we propose that reaction (3) was dominant, with a small contribution from the higher temperature reaction (4). Calcination of $\mathrm{UNH}$ in air at $600^{\circ} \mathrm{C}$ yielded $\mathrm{U}_{3} \mathrm{O}_{8}$, with a smaller amount of $\mathrm{UO}_{3}$ and $\mathrm{NO}_{2}$ gas. The higher temperature $\left(600^{\circ} \mathrm{C}\right)$ calcination of $\mathrm{UNH}$ in air probably favors reaction (4) over reaction (3), accounting for the higher yield of $\mathrm{U}_{3} \mathrm{O}_{8}$.

Calcination of $\mathrm{UNH}$ in $4 \% \mathrm{H}_{2} / 96 \% \mathrm{He}$ at $400^{\circ} \mathrm{C}$ yielded $\mathrm{U}_{3} \mathrm{O}_{8}, \mathrm{UO}_{3}$, and $\mathrm{NO}_{2}$ gas. These products indicate that reactions (3) and (4) occurred. The low concentration of $\mathrm{O}_{2}$ in the reaction 
vessel might favor reaction (4), accounting for the relatively high yield of $\mathrm{U}_{3} \mathrm{O}_{8}$ in the low temperature reaction. Calcination of $\mathrm{UNH}$ in $4 \% \mathrm{H}_{2} / 96 \% \mathrm{He}$ at $600^{\circ} \mathrm{C}$ yielded $\mathrm{UO}_{2}$ and $\mathrm{NO}_{2}$ gas. Reaction (5) is proposed as the dominant reaction in the higher temperature experiment in a reducing atmosphere.

\subsubsection{Summary}

The work reported here focuses on the sequence of reactions occurring during the evaporation/precipitation and calcination steps of the direct calcination process. Specific reactions have been proposed for each step. The primary reaction that occurs during the evaporation/precipitation step is evaporation of water and $\mathrm{HNO}_{3}$. The primary reaction that occurs during the calcination reactions is the denitration of $\mathrm{UNH}$.

The solid products of each step were identified in order to determine the reactions and to support the design of a waste storage system for a pilot- or production-scale facility. The solid product of the evaporation/precipitation step was UNH, regardless of experimental conditions. Solid products produced during calcinations in air were primarily $\mathrm{UO}_{3}$. When the calcination was carried out in a reducing atmosphere $\left(\mathrm{H}_{2} / \mathrm{He}\right.$ sparge gas), a mixture of $\mathrm{UO}_{3}$ and $\mathrm{U}_{3} \mathrm{O}_{8}$ was produced at $400^{\circ} \mathrm{C}$, and only $\mathrm{UO}_{2}$ was produced at $600^{\circ} \mathrm{C}$. These results suggest that higher temperature or a reducing atmosphere favor reduction of uranium.

The gaseous reaction products of each step were identified in order to support the design of off-gas systems for a pilot- or production-scale facility. The evaporation/precipitation step generates only very small amounts of gas. This suggests that little or no decomposition of the solid product (UNH) occurs. The primary off-gas from the calcinations of UNH was $\mathrm{NO}_{2}$, regardless of the experimental conditions. This shows that denitration of UNH is the dominant reaction during the calcination step.

\subsection{URANYL OXALATE PRECIPITATION PROCESS}

As indicated in Section 3.1, an alternative process was needed because of concerns about the splattering of uranium oxide calcination products, leading to equipment contamination and the generation of $\mathrm{NO}_{\mathrm{x}}$ gases that might cause regulatory problems. Several chemically assisted calcinations or denitration processes were proposed. Separating uranium by precipitation as uranyl peroxide and as uranyl oxalate was investigated. Uranyl oxalate proved difficult to filter and was rejected. On the other hand, the precipitation of uranyl oxalate in laboratory tests was a promising alternative to direct calcinations as a treatment process for the $\mathrm{UNH} / \mathrm{HNO} \mathrm{O}_{3}$ waste solutions expected from LEU-based ${ }^{99}$ Mo production.

Uranyl oxalate trihydrate $\left[\mathrm{UO}_{2}\left(\mathrm{C}_{2} \mathrm{O}_{4}\right) \cdot 3 \mathrm{H}_{2} \mathrm{O}\right]$ readily precipitates from uranyl salt solutions upon addition of oxalic acid. The precipitation is nearly complete; uranyl oxalate is less than $1 \mathrm{wt} \%$ soluble (at $25^{\circ} \mathrm{C}$ ) in the $1 \mathrm{M} \mathrm{HNO}_{3}$ solution typically found in these wastes. The solubility is about 5 times higher at $100^{\circ} \mathrm{C}$. The precipitation is optimized (i.e., the solubility is lowest) when there is a small excess of oxalic acid present. 
Studies were done to investigate the feasibility of the oxalate precipitation process for the treatment of $\mathrm{UNH} / \mathrm{HNO}_{3}$ waste solutions in our laboratory-scale calciner. In this process, $\mathrm{UNH} / \mathrm{HNO}_{3}$ solution was fed into the heated calciner cup containing solid oxalic acid. Water and $\mathrm{HNO}_{3}$ evaporated and uranyl oxalate formed by precipitation. After the feed was stopped, and the evaporation was complete, the temperature inside the calciner cup increased. At higher temperature, uranyl oxalate decomposes to a mixture of uranium oxides. The primary decomposition products in each experiment were $\mathrm{U}_{3} \mathrm{O}_{8}$ and $\mathrm{UO}_{2}$ with an in-cup density of about $1.3 \mathrm{~g} \mathrm{U} / \mathrm{mL}$.

\subsubsection{Evaporation}

\subsubsection{Solids}

Oxalic acid was placed in the glass calciner apparatus (Figure 1) followed by a $\mathrm{UNH} / \mathrm{HNO}_{3}$ solution; uranyl oxalate was precipitated. The mole ratio of oxalic acid to uranium was 1:1. The mixture was heated to evaporate the $\mathrm{HNO}_{3}$ and water, but not to decompose the salt. Experiments were done with air, $\mathrm{He}$, and $4 \% \mathrm{H}_{2} / 96 \% \mathrm{He}$ as sparge gases. These gases were used because of their redox potential; air is highly oxidizing, $\mathrm{He}$ is neutral, and $4 \% \mathrm{H}_{2} / 96 \% \mathrm{He}$ is reducing. The solids generated during the experiments were pale yellow. They were analyzed with XRD to confirm their composition. All of the solids formed, regardless of the sparge gas, were identified as uranyl oxalate hydrate (Figures 15-17).

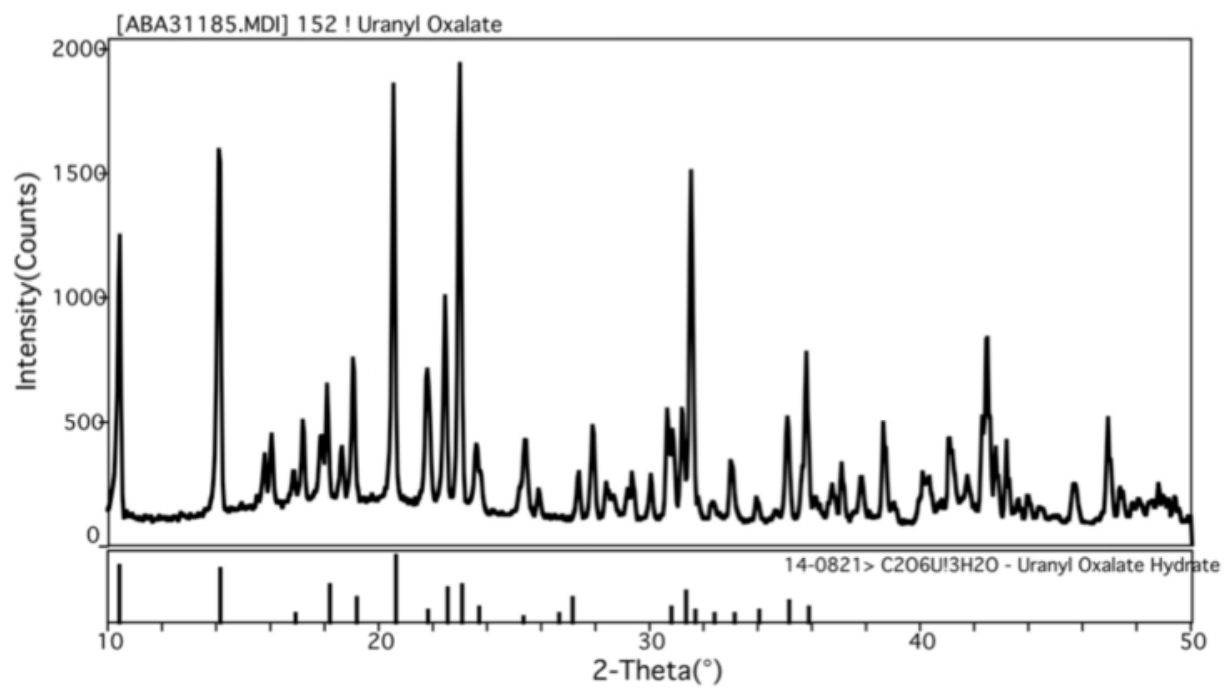

FIGURE 15 XRD pattern for solids formed by precipitation of uranyl oxalate and evaporation of $\mathrm{HNO}_{3}$ and water with air sparge gas 


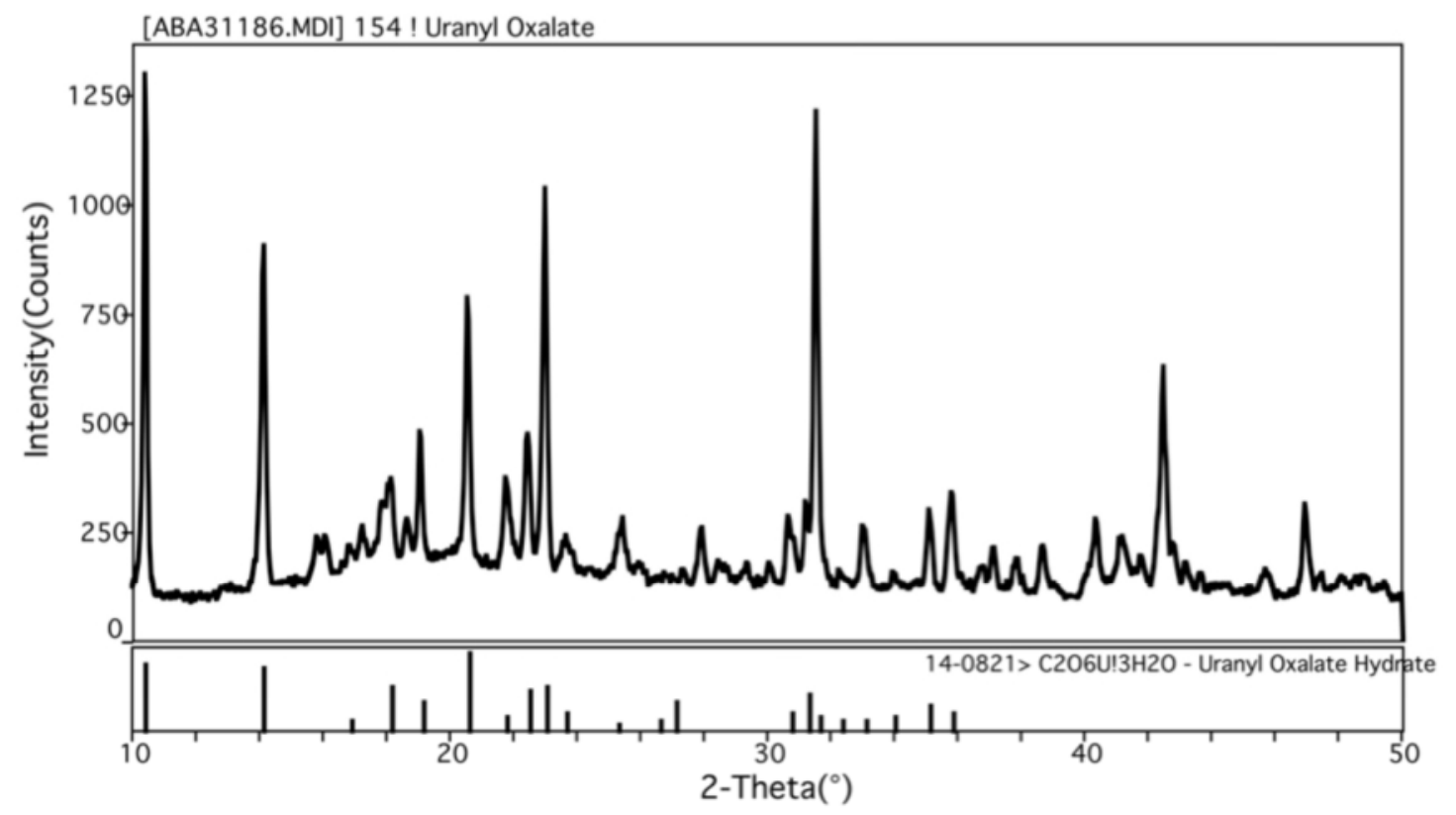

FIGURE 16 XRD pattern for solids formed by precipitation of uranyl oxalate and evaporation of $\mathrm{HNO}_{3}$ and water with $\mathrm{He}$ sparge gas

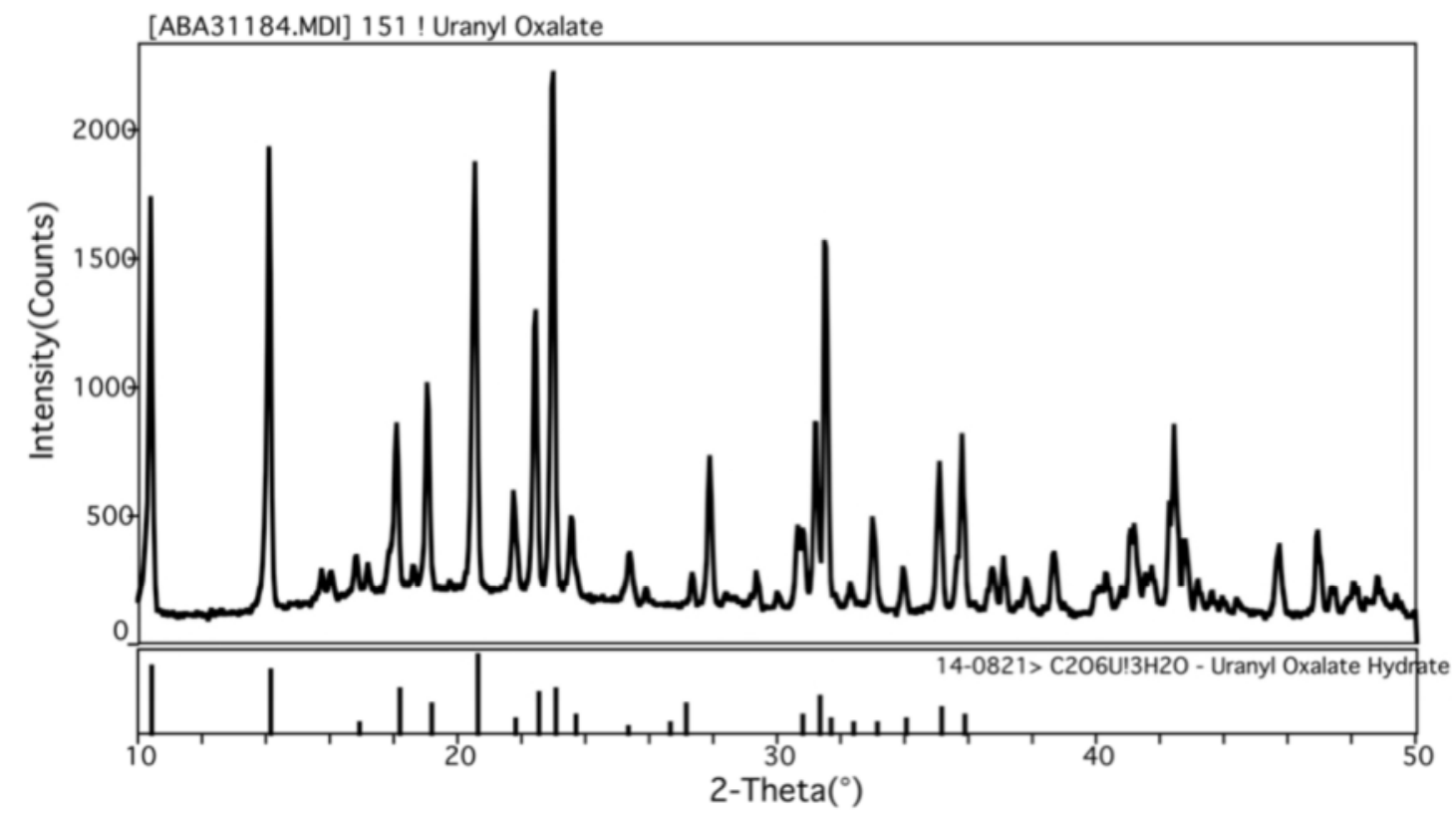

FIGURE 17 XRD pattern for solids formed by precipitation of uranyl oxalate and evaporation of $\mathrm{HNO}_{3}$ and water with $4 \% \mathrm{H}_{2} / 96 \%$ He sparge gas 


\subsubsection{Gases}

Several gas samples were collected during the above experiment and were analyzed for nitrogen and carbon oxide gases. Table 4 shows the results of the gas analyses. The samples from the experiment performed with air sparge gas contained significant amounts of $\mathrm{NO}_{2}$ and $\mathrm{CO}_{2}+$ $\mathrm{N}_{2} \mathrm{O}$, and one of the samples contained a small amount of NO. The samples from the experiment performed with $\mathrm{He}$ sparge gas contained significant amounts of all three gases. The most concentrated component in these samples, $\mathrm{CO}_{2}+\mathrm{N}_{2} \mathrm{O}$, becomes more concentrated as the evaporation/precipitation reaction continues. The samples from the experiment performed with $4 \% \mathrm{H}_{2} / 96 \% \mathrm{He}$ purge gas contained significant amounts of all three gases. Again the $\mathrm{CO}_{2}+\mathrm{N}_{2} \mathrm{O}$ concentration was higher than the other gases and increased in later samples. In these experiments, the $\mathrm{CO}_{2}+\mathrm{N}_{2} \mathrm{O}$ peak was attributed to $\mathrm{CO}_{2}$ derived from the degradation of oxalic acid.

TABLE 4 Concentrations (mol\%) of gases collected from evaporation and precipitation of uranyl oxalate

\begin{tabular}{lrrrrr}
\hline & $\begin{array}{c}\mathrm{CO}+\mathrm{N}_{2} \\
\mathrm{~m} / \mathrm{z}=28\end{array}$ & $\begin{array}{c}\mathrm{NO} \\
\mathrm{m} / \mathrm{z}=30\end{array}$ & $\begin{array}{c}\mathrm{O}_{2} \\
\mathrm{~m} / \mathrm{z}=32\end{array}$ & $\begin{array}{c}\mathrm{CO}_{2}+\mathrm{N}_{2} \mathrm{O} \\
\mathrm{m} / \mathrm{z}=44\end{array}$ & $\begin{array}{c}\mathrm{NO}_{2} \\
\mathrm{~m} / \mathrm{z}=46\end{array}$ \\
\hline Time ${ }^{\mathrm{a}}$ & & & & & \\
27 & & & & & \\
54 & $<0.01$ & $<0.01$ & $<0.01$ & 0.32 & 0.21 \\
68 & $<0.01$ & 0.07 & $<0.01$ & 0.43 & 0.11 \\
& $<0.01$ & 0.04 & $<0.01$ & 0.27 & 0.15 \\
$\mathrm{He}$ & & & & & \\
31 & & & & & \\
55 & $<0.01$ & 0.03 & $<0.01$ & 0.29 & 0.02 \\
65 & $<0.01$ & 0.06 & $<0.01$ & 0.48 & $<0.01$ \\
100 & 0.30 & 0.07 & $<0.01$ & 1.52 & 0.27 \\
& 1.65 & 0.34 & $<0.01$ & 4.19 & 0.12 \\
$4 \% \mathrm{H}_{2} / 96 \% \mathrm{He}$ & & & & & \\
25 & $<0.01$ & $<0.01$ & $<0.01$ & 0.17 & 0.01 \\
51 & $<0.01$ & $<0.01$ & $<0.01$ & 0.25 & 0.01 \\
84 & 0.35 & 0.07 & $<0.01$ & 1.38 & 0.01 \\
100 & 0.80 & 0.09 & $<0.01$ & 3.32 & 0.39 \\
\hline
\end{tabular}

a Number of minutes after furnace was turned on when sample was collected.

\subsubsection{Reactions}

The XRD pattern shows that uranyl oxalate was precipitated (reaction 6). The primary gaseous product was $\mathrm{CO}_{2}$. It was probably generated when oxalic acid decomposed to formic acid and $\mathrm{CO}_{2}$ above $150^{\circ} \mathrm{C}$ (reaction 7). Subsequently, formic acid could decompose under these conditions to water and $\mathrm{CO}$. The $\mathrm{NO}_{2}$ observed in these gas samples was probably derived from the reduction of nitrate ion. 


$$
\begin{gathered}
\mathrm{UO}_{2}\left(\mathrm{NO}_{3}\right)_{2}+\mathrm{H}_{2} \mathrm{C}_{2} \mathrm{O}_{4} \rightarrow \mathrm{UO}_{2}\left(\mathrm{C}_{2} \mathrm{O}_{4}\right)+2 \mathrm{HNO}_{3} \\
\mathrm{H}_{2} \mathrm{C}_{2} \mathrm{O}_{4} \rightarrow \mathrm{CO}_{2}+\mathrm{H}_{2} \mathrm{CO}_{2}
\end{gathered}
$$

\subsubsection{Calcinations}

A set of experiments was performed in the steel calciner to decompose (at $400^{\circ} \mathrm{C}$ and $600^{\circ} \mathrm{C}$ ) the uranyl oxalate from the previously described evaporation/precipitation experiments. The uranyl oxalate was calcined in the same atmosphere as it was precipitated. Gaseous products were collected throughout the calcinations. The experiment was held at the final temperature for at least 2 hours to ensure complete reaction. The calcinations were expected to generate solid uranium oxides and carbon oxide gases. The identity and proportions of these products allowed us to describe the reactions that occur during the calcination process.

\subsubsection{Solids}

Solids collected from the calcinations of uranyl oxalate in air, helium, and $4 \% \mathrm{H}_{2} / 96 \%$ He at $400^{\circ} \mathrm{C}$ and $600^{\circ} \mathrm{C}$ were collected and analyzed with XRD to determine their compositions. Table 5 summarizes the characteristics of the solid products from the calcinations.

TABLE 5 Characteristics of solid products of uranyl oxalate calcinations

\begin{tabular}{lll}
\hline & Appearance & Identification \\
\hline Air, $400^{\circ} \mathrm{C}$ & black/orange & $\mathrm{U}_{3} \mathrm{O}_{8}$ \\
Air, $600^{\circ} \mathrm{C}$ & black & $\mathrm{U}_{3} \mathrm{O}_{8}$ \\
$\mathrm{He}, 400^{\circ} \mathrm{C}$ & black & $\begin{array}{l}\mathrm{U}_{3} \mathrm{O}_{8} / \mathrm{UO}_{2} \\
(72 / 28)\end{array}$ \\
& & \\
$\mathrm{He}, 600^{\circ} \mathrm{C}$ & black & $\begin{array}{l}\mathrm{U}_{3} \mathrm{O}_{8} / \mathrm{UO}_{2} \\
(66 / 34)\end{array}$ \\
& & \\
$4 \% \mathrm{H}_{2} / 96 \% \mathrm{He}, 400^{\circ} \mathrm{C}$ & black & $\mathrm{U}_{3} \mathrm{O}_{8} / \mathrm{UO}_{2}$ \\
& & $(89 / 11)$ \\
$4 \% \mathrm{H}_{2} / 96 \% \mathrm{He}, 600^{\circ} \mathrm{C}$ & black & $\mathrm{UO}_{2}$ \\
\hline
\end{tabular}


The material calcined in air at $400^{\circ} \mathrm{C}$ showed the black color typical of $\mathrm{UO}_{2}$ and the orange color typical of $\mathrm{UO}_{3}$ (Figure 18, left side). However, its XRD pattern in Figure 19 shows that this material was primarily $\mathrm{U}_{3} \mathrm{O}_{8}$. The material calcined in air at $600^{\circ} \mathrm{C}$ was black (Figure 18, right side), and the XRD shows that the primary component of the calcined solid was again, $\mathrm{U}_{3} \mathrm{O}_{8}$ (Figure 20).

Both of the materials calcined in He were black (Figures 21). The XRD patterns of the materials calcined in $\mathrm{He}$ at $400^{\circ} \mathrm{C}$ and $600^{\circ} \mathrm{C}$ (Figures 22 and 23) show that these materials were mixtures of $\mathrm{UO}_{2}$ and $\mathrm{U}_{3} \mathrm{O}_{8}$. The material calcined at $600^{\circ} \mathrm{C}$ appeared to contain a high proportion of $\mathrm{UO}_{2}$, relative to the material calcined at $400^{\circ} \mathrm{C}$.

The materials calcined in $4 \% \mathrm{H}_{2} / 96 \%$ He were both black (Figure 24). The XRD patterns in Figures 25 and 26 show that the material calcined in $4 \% \mathrm{H}_{2} / 96 \% \mathrm{He}$ at $400^{\circ} \mathrm{C}$ was a mixture of $\mathrm{UO}_{2}$ and $\mathrm{U}_{3} \mathrm{O}_{8}$. The material calcined in $4 \% \mathrm{H}_{2} / 96 \% \mathrm{He}$ at $600^{\circ} \mathrm{C}$ was composed primarily of $\mathrm{UO}_{2}$.

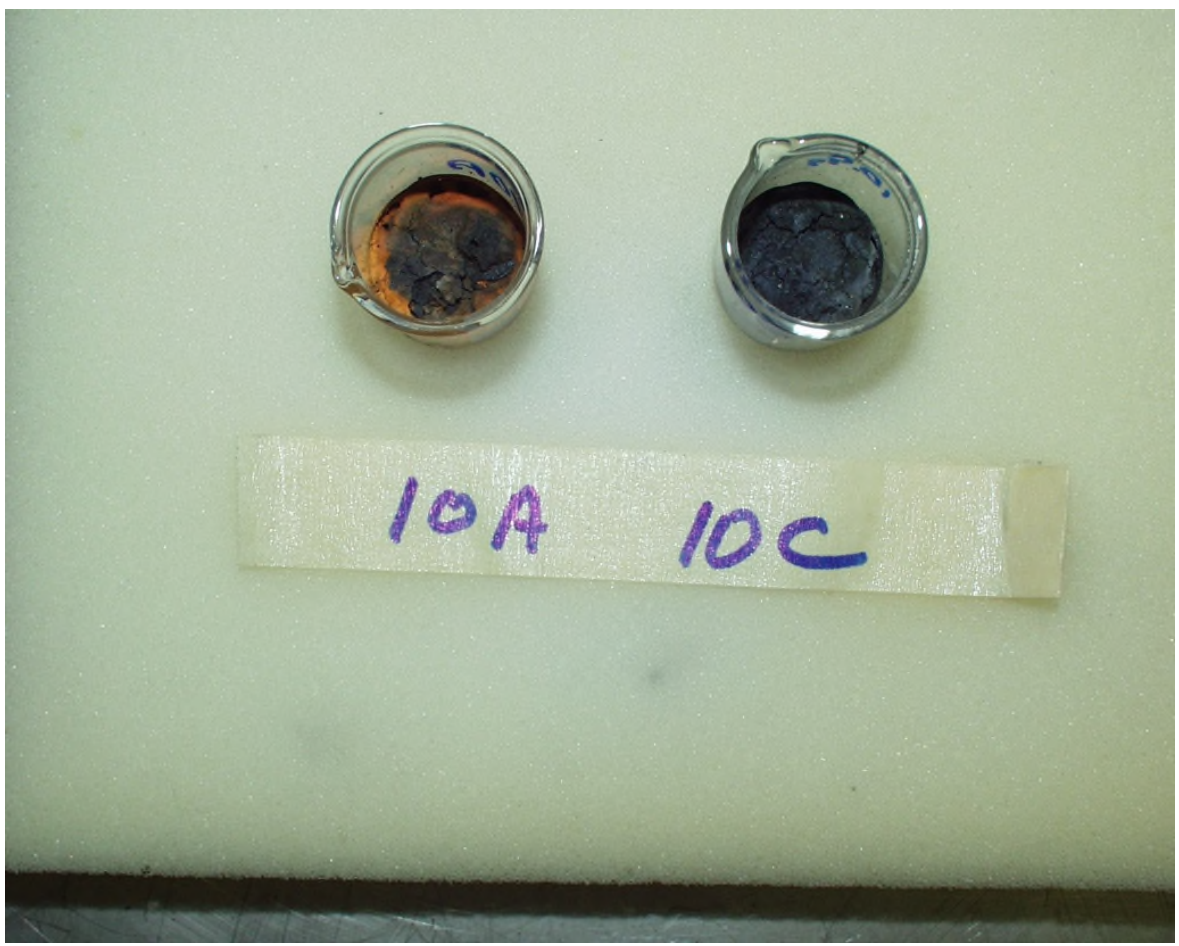

FIGURE 18 Photograph of material calcined in air at $400^{\circ} \mathrm{C}$ (left) and $600^{\circ} \mathrm{C}$ (right) from uranyl oxalate 


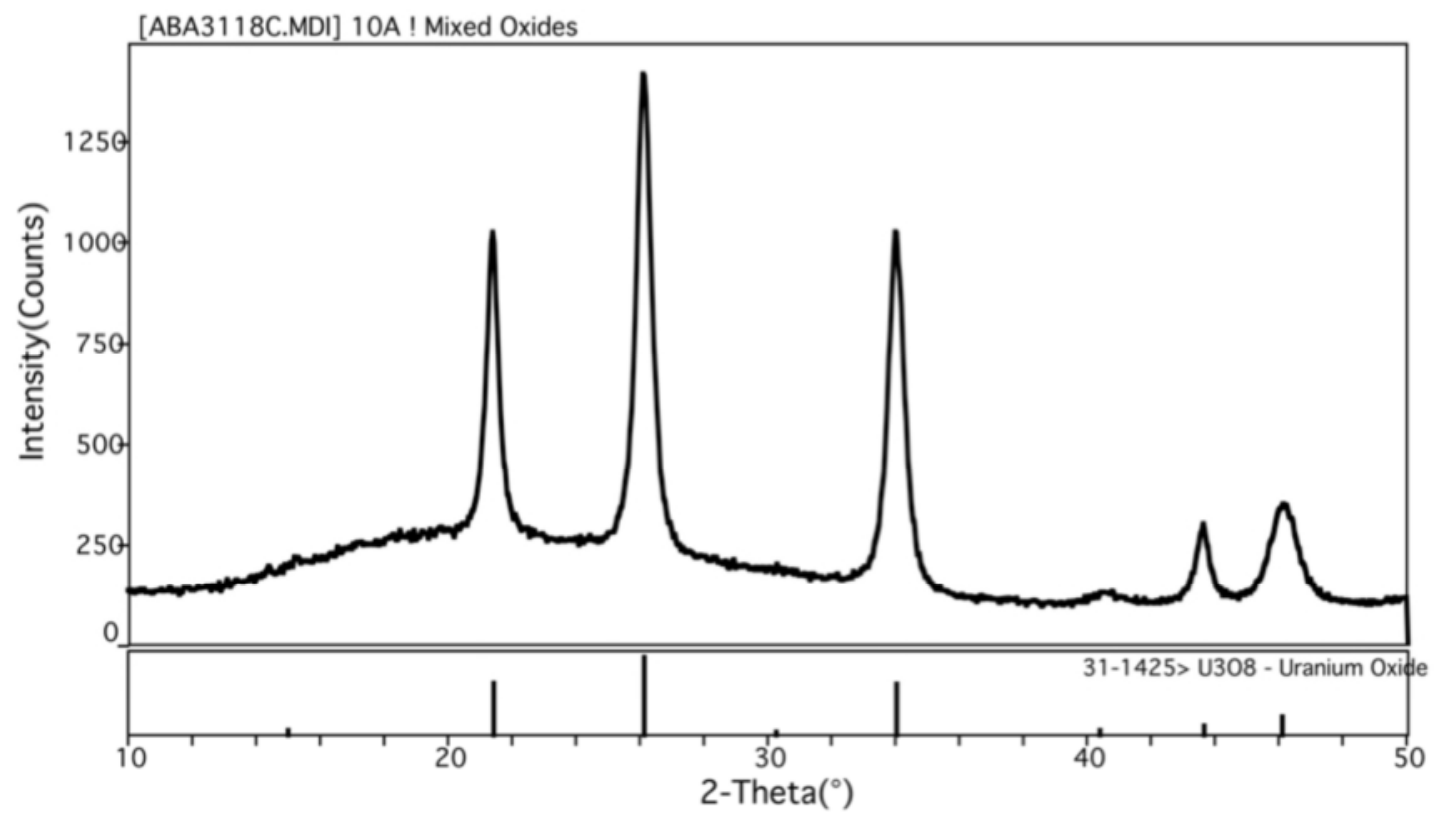

FIGURE 19 XRD pattern for solids formed by calcinations of uranyl oxalate at $400^{\circ} \mathrm{C}$ in air sweep gas

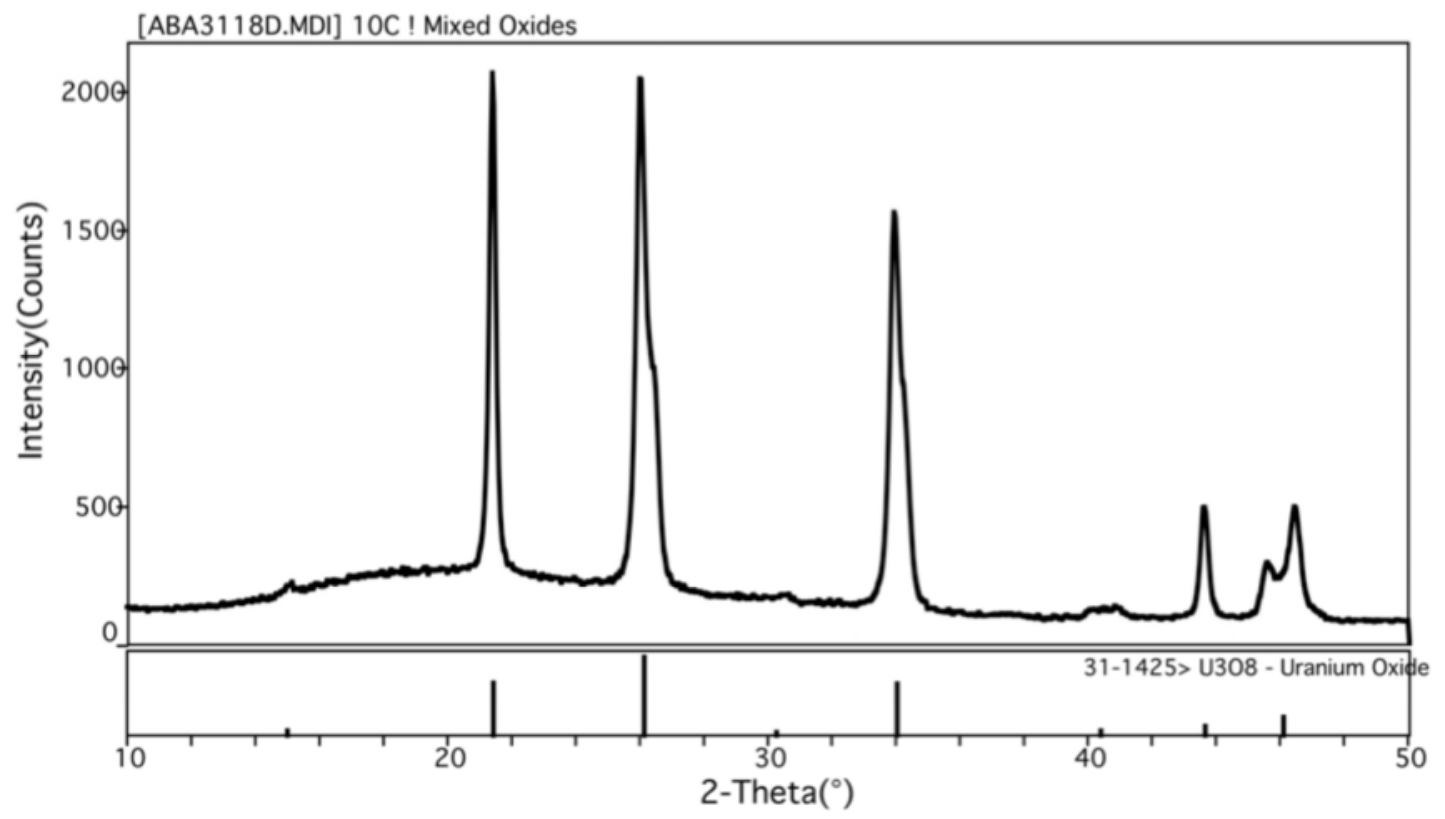

FIGURE 20 XRD pattern for solids formed by calcinations of uranyl oxalate at $600^{\circ} \mathrm{C}$ in air sweep gas 


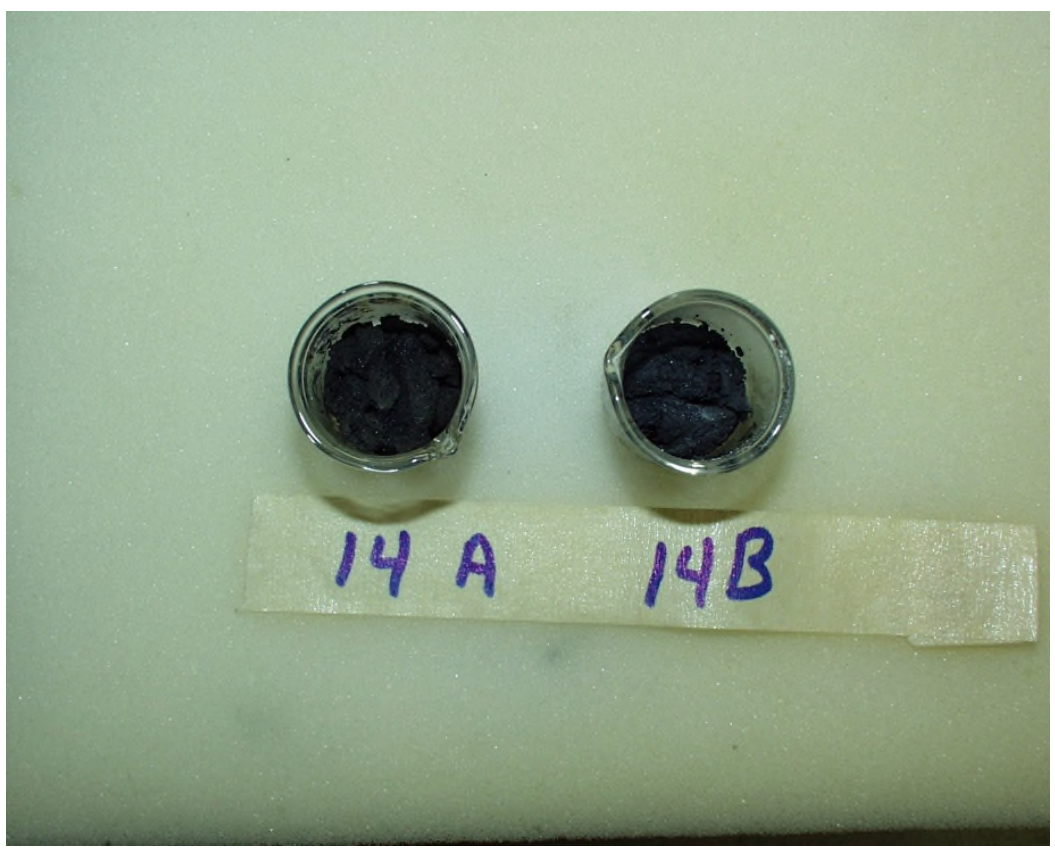

FIGURE 21 Photograph of material calcined in $\mathrm{He}$ at $400^{\circ} \mathrm{C}$ (left) and $600^{\circ} \mathrm{C}$ (right) from uranyl oxalate

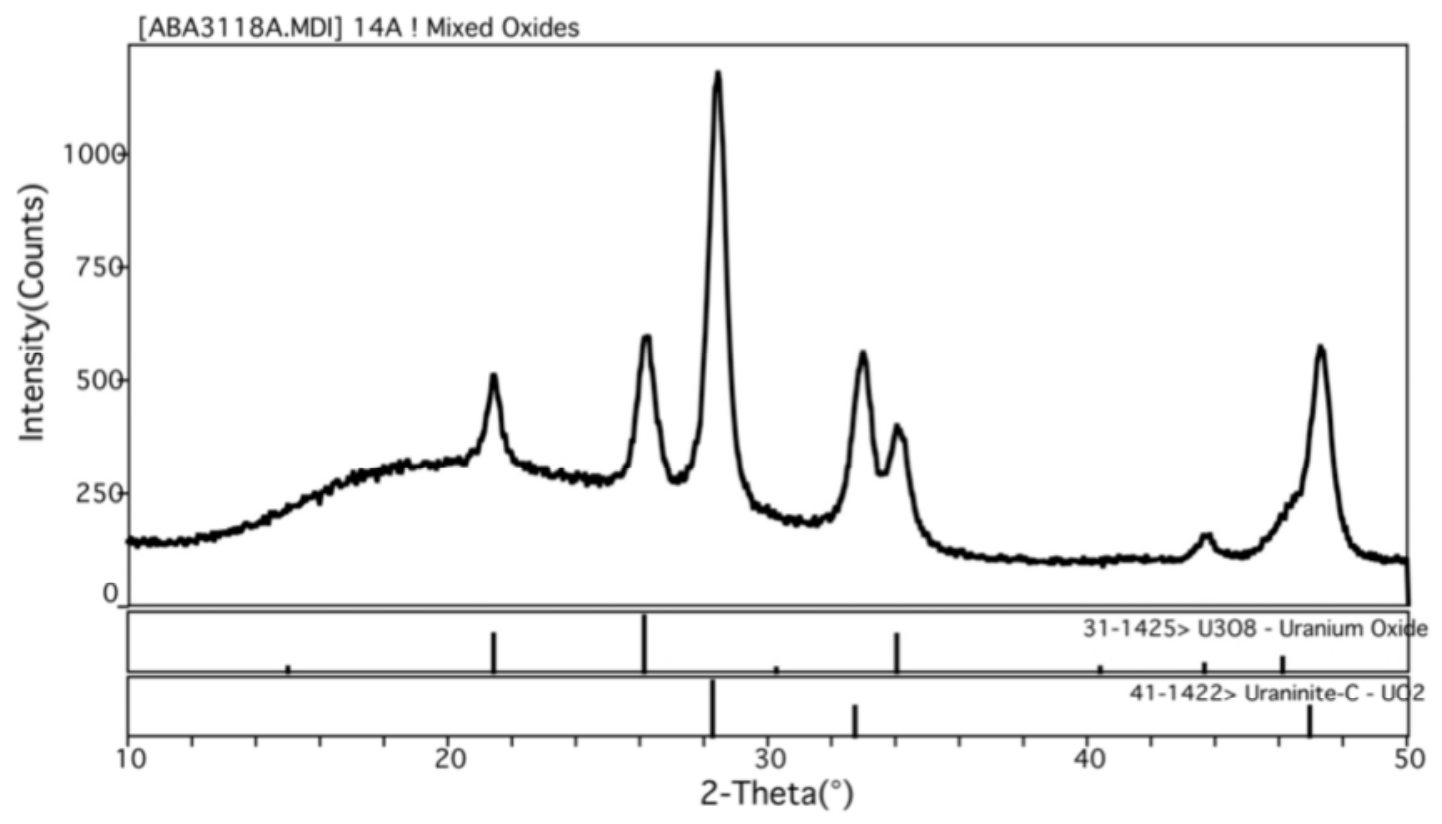

FIGURE 22 XRD pattern for solids formed by calcinations of uranyl oxalate at $400^{\circ} \mathrm{C}$ in He sweep gas 


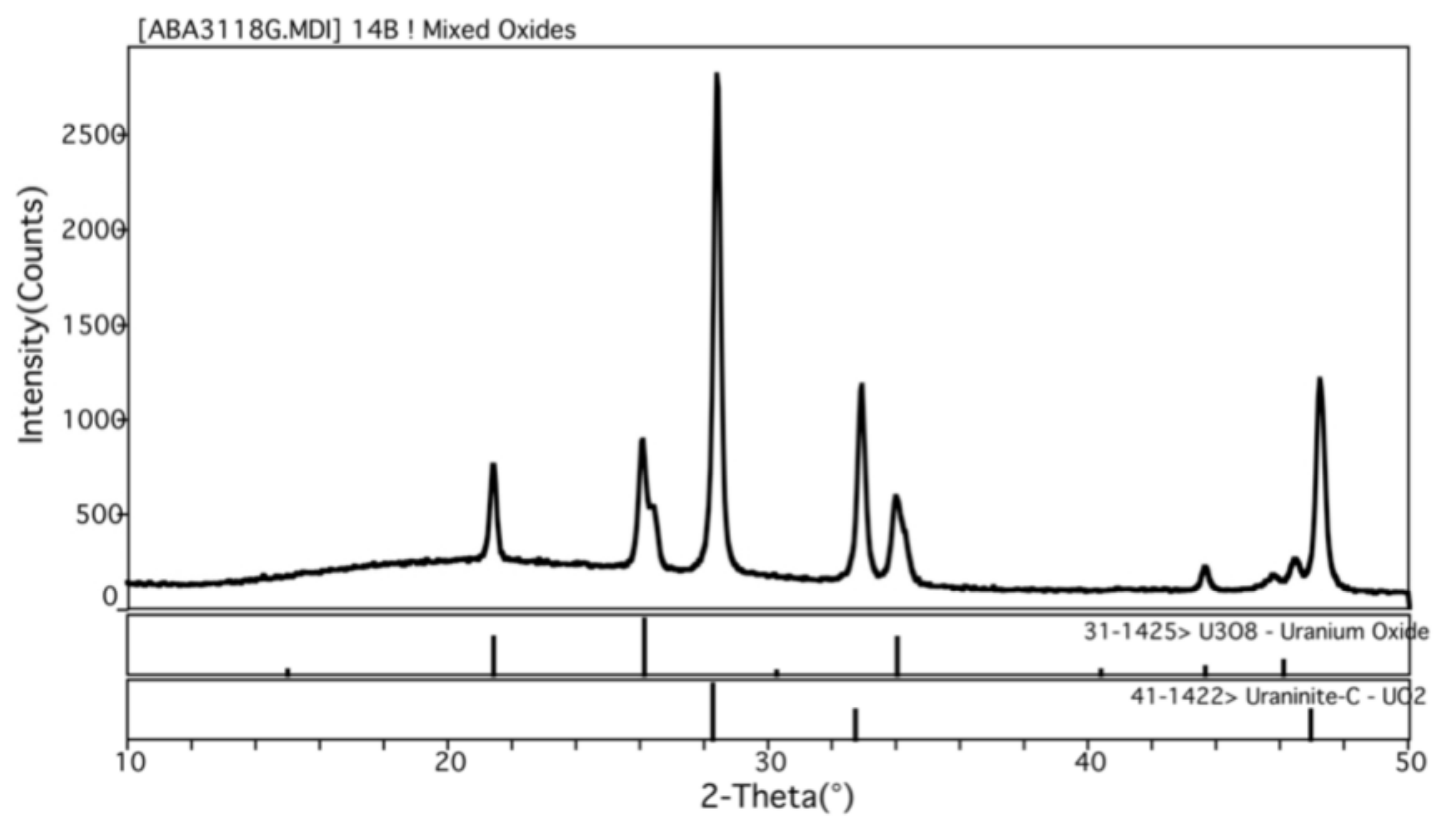

FIGURE 23 XRD pattern for solids formed by calcinations of uranyl oxalate at $600^{\circ} \mathrm{C}$ in He sweep gas

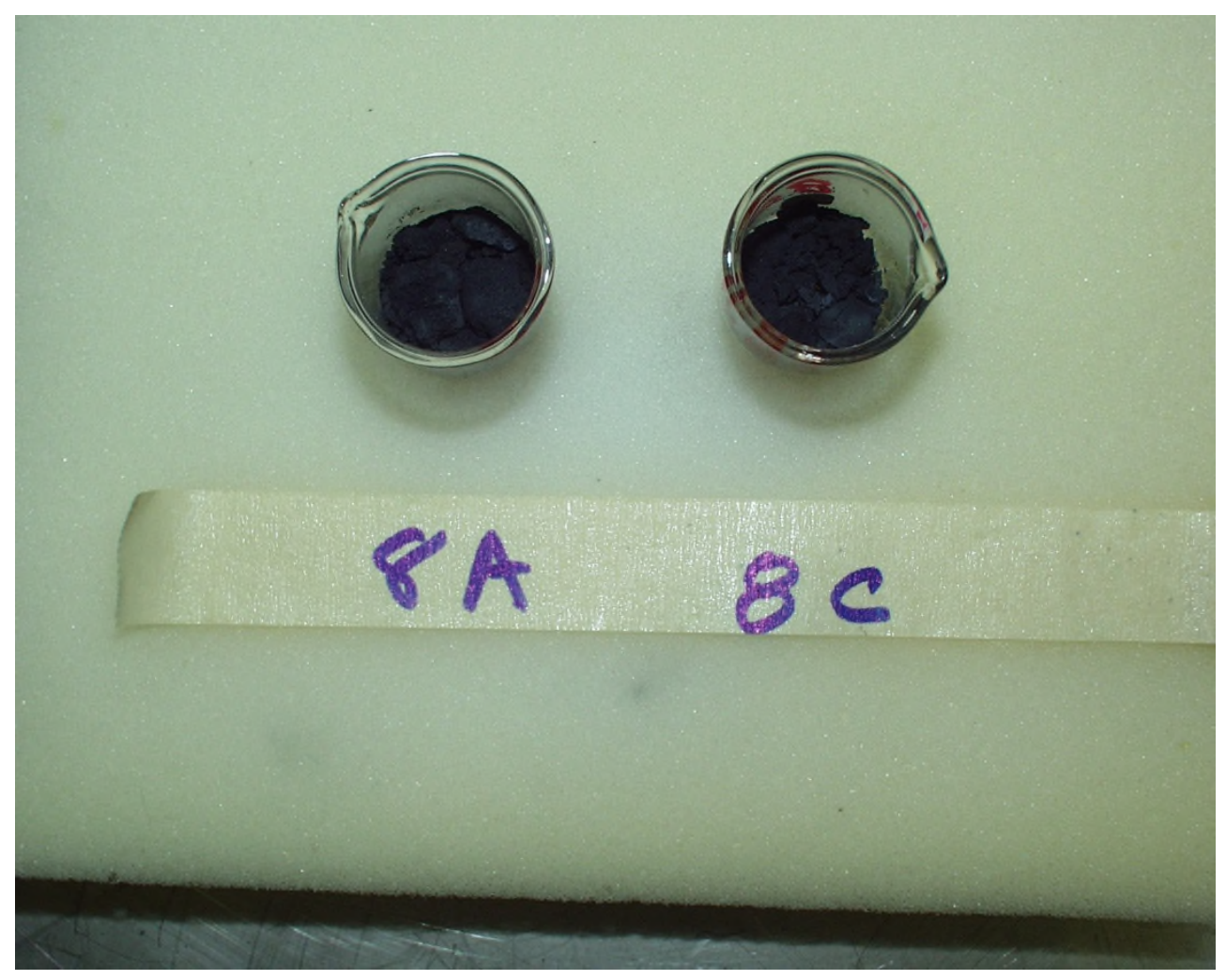

FIGURE 24 Photograph of material calcined in $4 \% \mathrm{H}_{2} / 96 \%$ He at $400^{\circ} \mathrm{C}$ (left) and $600^{\circ} \mathrm{C}$ (right) from uranyl oxalate 


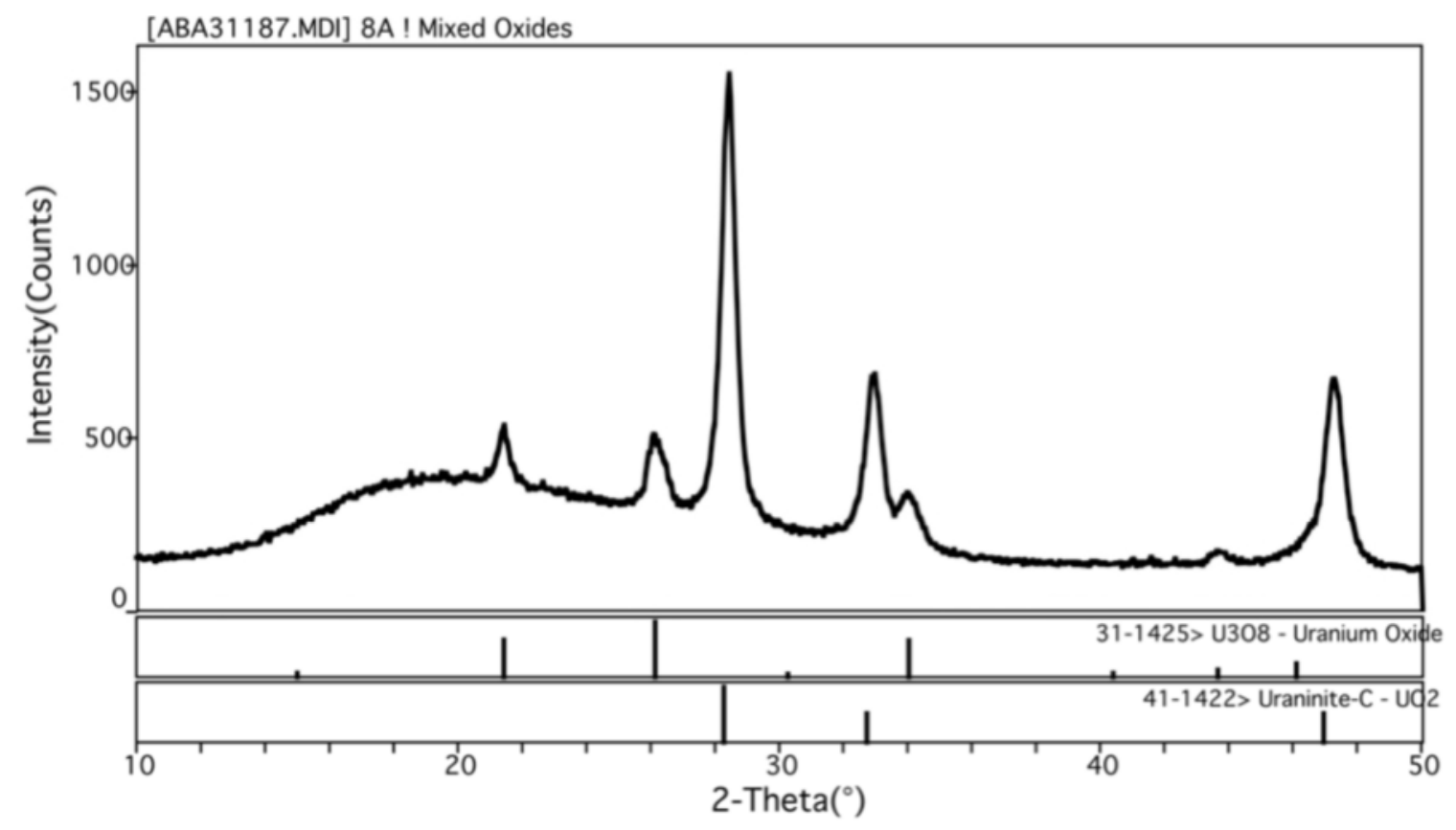

FIGURE 25 XRD pattern for solids formed by calcinations of uranyl oxalate at $400^{\circ} \mathrm{C}$ in $4 \% \mathrm{H}_{2} / 96 \%$ He sweep gas

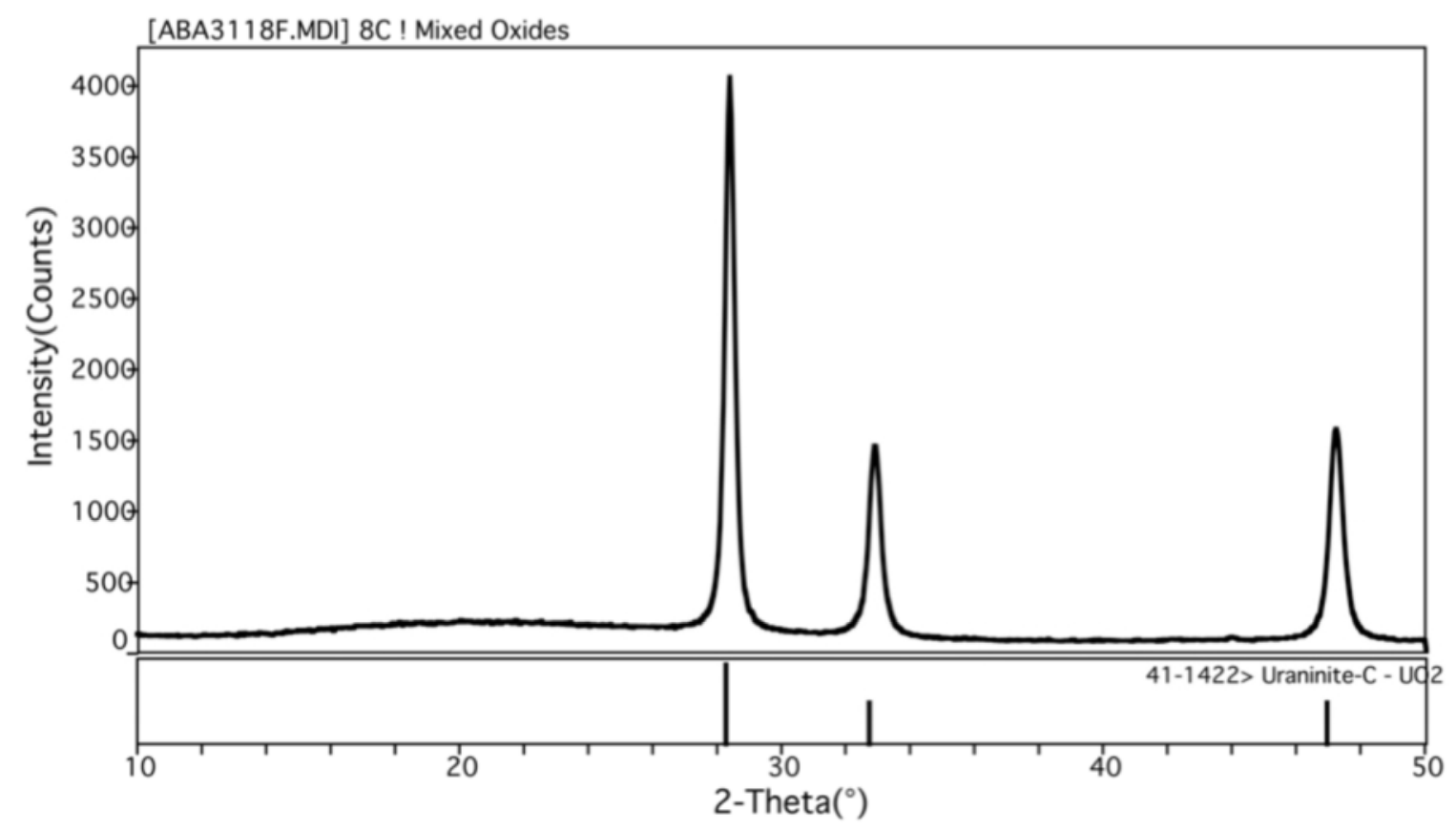

FIGURE 26 XRD pattern for solids formed by calcinations of uranyl oxalate at $600^{\circ} \mathrm{C}$ in $4 \% \mathrm{H}_{2} / 96 \%$ He sweep gas 


\subsubsection{Gases}

Gases were collected during the calcinations of uranyl oxalate and were analyzed with mass spectrometry (Table 6) to determine their compositions. Gas samples from the calcination experiments performed in air contained $\mathrm{CO}_{2}+\mathrm{N}_{2} \mathrm{O}$, less $\mathrm{NO}$, and small amounts of $\mathrm{NO}_{2}$. Gas samples from the experiments performed in He contained $\mathrm{CO}_{2}+\mathrm{N}_{2} \mathrm{O}$, less $\mathrm{NO}$, and small amounts of $\mathrm{NO}_{2}$; several gas samples also contained $\mathrm{CO}+\mathrm{N}_{2}$. Gas samples from the experiments performed in $4 \% \mathrm{H}_{2} / 96 \%$ He contained small amounts of $\mathrm{CO}_{2}+\mathrm{N}_{2} \mathrm{O}$, NO, and less $\mathrm{NO}_{2}$; one gas sample contained $\mathrm{CO}+\mathrm{N}_{2}$.

A TGA analysis was conducted on solid uranyl oxalate samples from the evaporation/precipitation experiments. Because the TGA was run with an air purge gas, the results should compare to our calcination results with air sweep gas. Figure 27 shows that the major products of the TGA experiment were water (evolved at $130-330^{\circ} \mathrm{C}$ ) and $\mathrm{CO}$ and $\mathrm{CO}_{2}$ (evolved at $330-430^{\circ} \mathrm{C}$ ).

The TGA results are consistent with our interpretations of the calcination gas data. The water detected during TGA experiments was not detected in the gases collected during our calcinations because any water evolved would have condensed. The major gaseous product of our calcinations of uranyl oxalate in air sweep gas was $\mathrm{CO}_{2}$ (Table 6). Note that $\mathrm{CO}$ generates the same molecular fragment as $\mathrm{N}_{2}$ and, thus, was not detected by mass spectrometry in the presence of air. Therefore, the TGA results are consistent with the results from the calcination experiments. Specifically, $\mathrm{CO}$ and $\mathrm{CO}_{2}$ are the major gases generated during the calcination of uranyl oxalate in air.

\subsubsection{Reactions}

The calcination of uranyl oxalate under these experimental conditions is a combination of several complex reactions. The present data do not allow us to rigorously determine all of the reactions, or the stoichiometry of the overall reaction. However, the products observed, and their relative abundance, allow us to propose three reactions that occur during the calcinations:

$$
\begin{gathered}
3 \mathrm{UO}_{2} \mathrm{C}_{2} \mathrm{O}_{4}+\mathrm{O}_{2} \rightarrow \mathrm{U}_{3} \mathrm{O}_{8}+6 \mathrm{CO}_{2} \\
\mathrm{H}_{2} \mathrm{C}_{2} \mathrm{O}_{4} \rightarrow \mathrm{H}_{2} \mathrm{O}+\mathrm{CO}+\mathrm{CO}_{2} \\
\mathrm{UO}_{2} \mathrm{C}_{2} \mathrm{O}_{4} \rightarrow \mathrm{UO}_{2}+2 \mathrm{CO}_{2}
\end{gathered}
$$

Calcination of uranyl oxalate in air at both $400^{\circ} \mathrm{C}$ and $600^{\circ} \mathrm{C}$ yielded $\mathrm{U}_{3} \mathrm{O}_{8}$ and $\mathrm{CO}_{2}$ gas. Therefore, we propose that reaction (8) was dominant under oxidizing conditions. The TGA results show that $\mathrm{CO}$ is also generated during the calcination of uranyl oxalate. Reaction (9) shows the degradation of any residual oxalic acid to $\mathrm{CO}$. Calcination of uranyl oxalate in He, at both $400^{\circ} \mathrm{C}$ and $600^{\circ} \mathrm{C}$, yielded mixtures of $\mathrm{UO}_{2}, \mathrm{U}_{3} \mathrm{O}_{8}$, and $\mathrm{CO}_{2}$ gas. Therefore, both reaction (8) and (10) occur under these conditions. Comparison of Figures 22 and 23 suggest that there 
TABLE 6 Concentrations (mol \%) of gases collected from calcinations of uranyl oxalate solids

\begin{tabular}{|c|c|c|c|c|c|}
\hline Time $^{\mathrm{a}}$ & $\begin{array}{l}\mathrm{CO}+\mathrm{N}_{2} \\
\mathrm{~m} / \mathrm{z}=28\end{array}$ & $\begin{array}{c}\mathrm{NO} \\
\mathrm{m} / \mathrm{z}=30\end{array}$ & $\begin{array}{c}\mathrm{O}_{2} \\
\mathrm{~m} / \mathrm{z}=32\end{array}$ & $\begin{array}{c}\mathrm{CO}_{2}+\mathrm{N}_{2} \mathrm{O} \\
\mathrm{m} / \mathrm{z}=44\end{array}$ & $\begin{array}{c}\mathrm{NO}_{2} \\
\mathrm{~m} / \mathrm{z}=46\end{array}$ \\
\hline \multicolumn{6}{|l|}{ Air, $400^{\circ} \mathrm{C}$} \\
\hline 18 & $<0.01$ & 0.15 & $<0.01$ & 0.12 & $<0.01$ \\
\hline 26 & $<0.01$ & 0.25 & $<0.01$ & 0.32 & $<0.01$ \\
\hline 31 & $<0.01$ & $<0.01$ & $<0.01$ & 0.33 & 0.03 \\
\hline 41 & $<0.01$ & $<0.01$ & $<0.01$ & 0.29 & $<0.01$ \\
\hline 51 & $<0.01$ & $<0.01$ & $<0.01$ & 0.15 & $<0.01$ \\
\hline \multicolumn{6}{|l|}{ Air, $600^{\circ} \mathrm{C}$} \\
\hline 10 & $<0.01$ & 0.01 & $<0.01$ & 0.03 & 0.01 \\
\hline 16 & $<0.01$ & 0.11 & $<0.01$ & 0.36 & 0.03 \\
\hline 22 & $<0.01$ & 0.06 & $<0.01$ & 1.38 & 0.08 \\
\hline 33 & $<0.01$ & 0.15 & $<0.01$ & 0.12 & $<0.01$ \\
\hline 44 & $<0.01$ & 0.07 & $<0.01$ & 0.06 & $<0.01$ \\
\hline 54 & $<0.01$ & $<0.01$ & $<0.01$ & 0.03 & 0.06 \\
\hline \multicolumn{6}{|l|}{$\mathrm{He}, 400^{\circ} \mathrm{C}$} \\
\hline 15 & $<0.01$ & 0.07 & $<0.01$ & 0.09 & 0.02 \\
\hline 20 & 0.04 & 0.29 & $<0.01$ & 0.15 & 0.03 \\
\hline 30 & 0.27 & $<0.01$ & $<0.01$ & 2.35 & 0.02 \\
\hline 40 & 0.20 & $<0.01$ & $<0.01$ & 0.03 & 0.02 \\
\hline 50 & $<0.01$ & $<0.01$ & $<0.01$ & 0.03 & 0.03 \\
\hline \multicolumn{6}{|l|}{$\mathrm{He}, 600^{\circ} \mathrm{C}$} \\
\hline 20 & $<0.01$ & 0.15 & $<0.01$ & 0.10 & 0.03 \\
\hline 25 & 0.18 & 0.63 & $<0.01$ & 1.23 & 0.07 \\
\hline 35 & $<0.01$ & 0.03 & $<0.01$ & 0.04 & 0.01 \\
\hline 45 & $<0.01$ & 0.02 & $<0.01$ & 0.04 & 0.01 \\
\hline \multicolumn{6}{|c|}{$\begin{array}{l}4 \% \mathrm{H}_{2} / 96 \% \mathrm{He}, \\
400^{\circ} \mathrm{C}\end{array}$} \\
\hline 15 & $<0.01$ & 0.08 & $<0.01$ & 0.06 & 0.01 \\
\hline 24 & 0.43 & 0.11 & $<0.01$ & 0.28 & 0.03 \\
\hline 35 & $<0.01$ & $<0.01$ & $<0.01$ & 0.05 & $<0.01$ \\
\hline 45 & $<0.01$ & 0.01 & $<0.01$ & 0.01 & $<0.01$ \\
\hline \multicolumn{6}{|c|}{$\begin{array}{l}4 \% \mathrm{H}_{2} / 96 \% \mathrm{He}, \\
600^{\circ} \mathrm{C}\end{array}$} \\
\hline 15 & $<0.01$ & 0.14 & $<0.01$ & 0.06 & $<0.01$ \\
\hline 20 & $<0.01$ & 0.15 & $<0.01$ & 0.15 & $<0.01$ \\
\hline 30 & $<0.01$ & 0.32 & $<0.01$ & 0.13 & 0.11 \\
\hline 40 & $<0.01$ & 0.53 & $<0.01$ & 0.16 & 0.03 \\
\hline 50 & $<0.01$ & $<0.01$ & $<0.01$ & 0.01 & 0.03 \\
\hline 60 & $<0.01$ & 0.01 & $<0.01$ & $<0.01$ & 0.01 \\
\hline
\end{tabular}

a Number of minutes after furnace was turned on when sample was collected. 


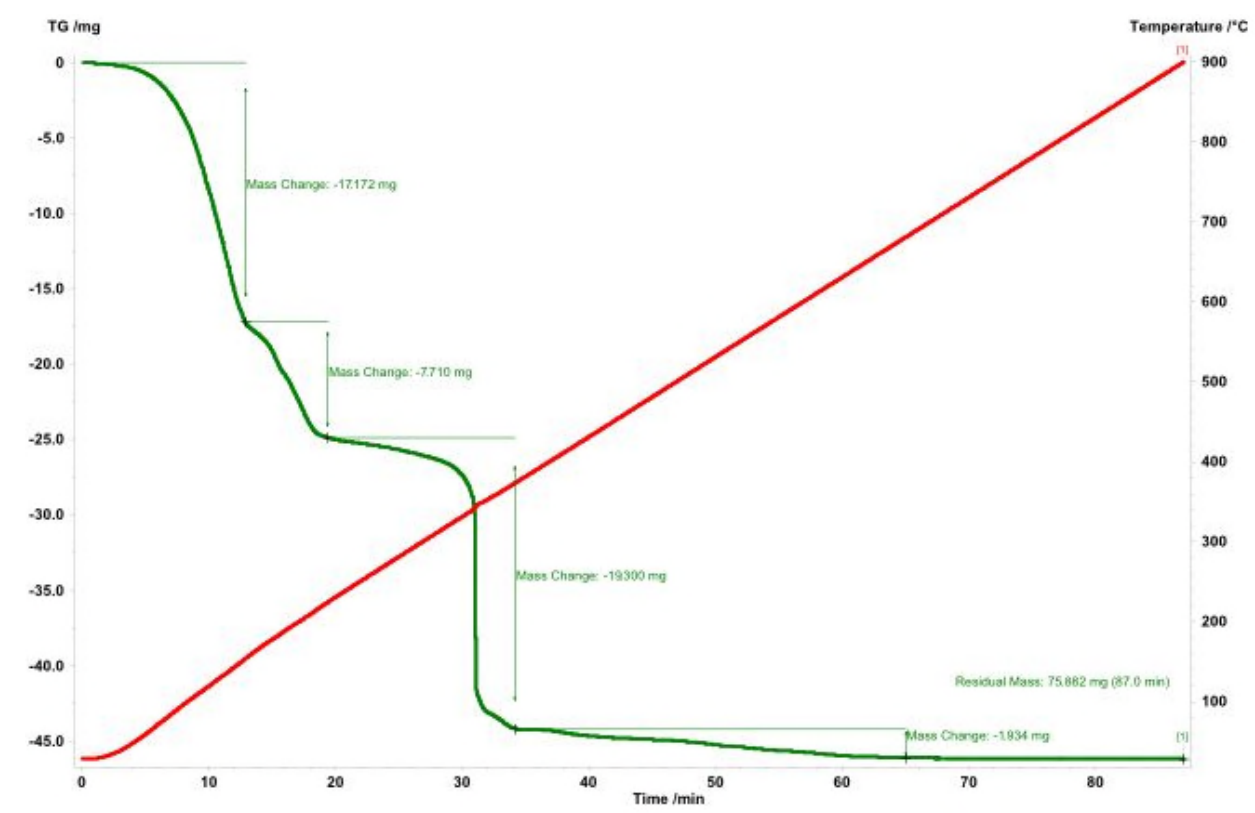

FIGURE 27 TGA results from analysis of uranyl oxalate

was more $\mathrm{UO}_{2}$ formed in the $600^{\circ} \mathrm{C}$ calcination than in the $400^{\circ} \mathrm{C}$ calcination in helium. Calcination of uranyl oxalate in $4 \% \mathrm{H}_{2} / 96 \% \mathrm{He}$ at $400^{\circ} \mathrm{C}$ yielded a mixture of $\mathrm{UO}_{2}, \mathrm{U}_{3} \mathrm{O}_{8}$, and $\mathrm{CO}_{2}$ gas. Again, a combination of reactions (8) and (10) is suggested. Calcination of uranyl oxalate in $4 \% \mathrm{H}_{2} / 96 \% \mathrm{He}$ at $600^{\circ} \mathrm{C}$ yielded a mixture of $\mathrm{UO}_{2}$ and $\mathrm{CO}_{2}$ gas. These products are consistent with reaction (10).

\subsubsection{Summary}

The work reported here focuses on the reactions occurring during the evaporation/precipitation and calcination steps for the uranyl oxalate process. Specific reactions have been proposed for each step. The primary reactions that occur during the evaporation/precipitation step are the precipitation of uranyl oxalate and the evaporation of water and $\mathrm{HNO}_{3}$. The primary reaction that occurs during the calcination step is the degradation of uranyl oxalate to $\mathrm{UO}_{2}, \mathrm{U}_{3} \mathrm{O}_{8}, \mathrm{CO}$, and $\mathrm{CO}_{2}$.

The solid products of each step were identified in order to determine the reactions and to support the design of a waste storage system for a pilot- or production-scale facility. The solid product of the evaporation/precipitation step was uranyl oxalate trihydrate, regardless of experimental conditions. Solid products produced during calcinations in air were primarily $\mathrm{U}_{3} \mathrm{O}_{8}$. When the calcinations were carried out in $\mathrm{He}$, mixtures of $\mathrm{U}_{3} \mathrm{O}_{8}$ and $\mathrm{UO}_{2}$ were formed. Calcinations carried out in a reducing atmosphere $\left(4 \% \mathrm{H}_{2} / 96 \% \mathrm{He}\right)$ at $400^{\circ} \mathrm{C}$ generated a mixture of $\mathrm{U}_{3} \mathrm{O}_{8}$ and $\mathrm{UO}_{2}$, and at $600^{\circ} \mathrm{C}, \mathrm{UO}_{2}$. These results suggest that higher temperature and a reducing atmosphere favor reduction of uranium. 
The gaseous reaction products of each step were identified in order to support the design of off-gas systems for a pilot- or production-scale facility. The evaporation/precipitation step generated only very small amounts of $\mathrm{NO}_{2}$ gas. The absence of carbon oxide gases suggests very little decomposition of the oxalic acid or uranyl oxalate during this step. The primary off-gases from the calcination step are $\mathrm{CO}$ and $\mathrm{CO}_{2}$. The decomposition of oxalate is probably the primary source of this gas. Based on the gas and solids compositions, we have suggested some possible chemical reactions that occur during the process.

\subsection{COMPARISON OF THE TWO PROCESSES}

The data presented here can be used to compare the direct calcination process to the oxalate precipitation process for treatment of the expected $\mathrm{UNH} / \mathrm{HNO}_{3}$ waste solutions from LEU-based ${ }^{99}$ Mo production.

Our earlier studies showed that the direct calcination process yields a higher density product than the uranyl oxalate process. Therefore, without a compaction step, the oxalate process would allow for less uranium in each calciner cup. The additional cups needed for implementation of the oxalate process would impact the solid waste treatment and storage facilities. On the other hand, no splattering was observed during the oxalate precipitation process, while splattering was a significant problem during the direct calcination process. The observed splattering might lead to contamination of the calciner equipment, which might impact the safety and downtime of the operation.

The present study compared the solid and gaseous products from the calcinations of the UNH and oxalate processes (Table 7). Under most conditions, calcination of the UNH yields a mixture of $\mathrm{UO}_{3}$ and $\mathrm{U}_{3} \mathrm{O}_{8}$, and calcination of uranyl oxalate yields $\mathrm{UO}_{2}$. The primary off-gas from calcination of $\mathrm{UNH}$ in this study is $\mathrm{NO}_{2}$, and the primary off-gas from calcination of uranyl oxalate is $\mathrm{CO}_{2}$. Therefore, these two processes present two alternatives, and are different operationally and with respect to their products. The data in this report can form the basis of a decision between the two processes. 
TABLE 7 Primary products of calcinations reactions

\begin{tabular}{cll}
\hline & \multicolumn{1}{c}{$\mathrm{UNH}$} & \multicolumn{1}{c}{ Oxalate } \\
\hline & & \\
Air-solid & & \\
$400^{\circ} \mathrm{C}$ & $\mathrm{UO}_{3} / \mathrm{U}_{3} \mathrm{O}_{8}$ & $\mathrm{U}_{3} \mathrm{O}_{8}$ \\
$600^{\circ} \mathrm{C}$ & $\mathrm{UO}_{3} / \mathrm{U}_{3} \mathrm{O}_{8}$ & $\mathrm{U}_{3} \mathrm{O}_{8}$ \\
Air-gas & & \\
$400^{\circ} \mathrm{C}$ & $\mathrm{NO}_{2}$ & $\mathrm{CO}_{2}$ \\
$600^{\circ} \mathrm{C}$ & $\mathrm{NO}_{2}$ & $\mathrm{CO}_{2}$ \\
$\mathrm{He}-\mathrm{solid}$ & & \\
$400^{\circ} \mathrm{C}$ & & $\mathrm{U}_{3} \mathrm{O}_{8} / \mathrm{UO}_{2}$ \\
$600^{\circ} \mathrm{C}$ & & $\mathrm{U}_{3} \mathrm{O}_{8} / \mathrm{UO}_{2}$ \\
$\mathrm{He}-$ gas & & \\
$400^{\circ} \mathrm{C}$ & & $\mathrm{CO}_{2}$ \\
$600^{\circ} \mathrm{C}$ & & $\mathrm{CO}_{2}$ \\
& & \\
$4 \% \mathrm{H}_{2} / 96 \%$ He-solid & & \\
$400^{\circ} \mathrm{C}$ & $\mathrm{UO}_{3} / \mathrm{U}_{3} \mathrm{O}_{8}$ & $\mathrm{U}_{3} \mathrm{O}_{8} / \mathrm{UO}_{2}$ \\
$600^{\circ} \mathrm{C}$ & $\mathrm{UO}_{2}$ & $\mathrm{UO}_{2}$ \\
& & \\
$4 \% \mathrm{H}_{2} / 96 \%$ He-gas & & \\
$400^{\circ} \mathrm{C}$ & $\mathrm{NO}_{2}$ & $\mathrm{CO}_{2}$ \\
$600^{\circ} \mathrm{C}$ & $\mathrm{NO}_{2}$ & $\mathrm{NO}^{2}$ \\
\hline
\end{tabular}




\section{CONCLUSION}

Two processes were investigated for treating UHN/ $/ \mathrm{NO}_{3}$ waste from ${ }^{99}$ Mo production: direct calcination of the $\mathrm{UNH} / \mathrm{HNO}_{3}$ solution, and oxalate precipitation followed by calcination of the uranyl oxalate precipitate. A series of experiments was conducted to characterize the chemical reactions that occur during the precipitation/evaporation and calcination steps for both processes. Three sparge gases (air, helium, and $4 \% \mathrm{H}_{2} / 96 \% \mathrm{He}$ ) were used to show the effect of the redox potential of the atmosphere on the reaction products. Calcinations were carried out at $400^{\circ} \mathrm{C}$ and $600^{\circ} \mathrm{C}$ to show the effects of temperature on the reaction products. Solid and gaseous products of the reactions were collected and characterized.

The direct calcination process yielded a mixture of $\mathrm{UO}_{3}$ and $\mathrm{U}_{3} \mathrm{O}_{8}$ under most of the conditions used in this study. The primary gaseous product of this reaction, under all conditions, was $\mathrm{NO}_{2}$. Calcination of uranyl oxalate yielded a mixture of $\mathrm{U}_{3} \mathrm{O}_{8}$ and $\mathrm{UO}_{2}$ under most of the conditions used in this study. Calcination at $600^{\circ} \mathrm{C}$ in a reducing atmosphere yielded $\mathrm{UO}_{2}$. The primary gaseous product of this reaction, in most of our experiments, was $\mathrm{CO}_{2}$.

The data presented here point out differences in these two processes. The direct calcination process yields a product with a density of about $3 \mathrm{~g} \mathrm{U} / \mathrm{ml}$, results in splattering, and generates a significant amount of $\mathrm{NO}_{2}$ gas. The oxalate precipitation process yields a product with a density of about $1.3 \mathrm{~g} \mathrm{U} / \mathrm{mL}$, results in no splattering, and generates primarily $\mathrm{CO}_{2}$ gas. 


\section{REFERENCES}

[BAKEL-2016] Allen J. Bakel, Cliff Conner, Kevin Quigley, and George F. Vandegrift, Waste Treatment of Acidic Solutions from the Dissolution of Irradiated LEU Targets for ${ }^{99} \mathrm{Mo}$ Production, Argonne National Laboratory, ANL/NE-16/21 (2016).

[HANST-1990] P. L. Hanst, and S. T. Hanst, Gas Analysis Manual for Analytical Chemists, Part II: Quantitative Reference Spectra for Gas Analysis, Infrared Analysis, Anaheim, CA (1990). 



\section{Argonne}

Nuclear Engineering Division

Argonne National Laboratory

9700 South Cass Avenue, Bldg. 208

Argonne, IL 60439-4854

www.anl.gov

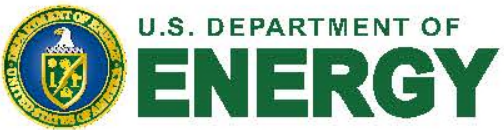

Argonne National Laboratory is a U.S. Department of Energy

laboratory managed by UChicago Argonne, LLC 